NBER WORKING PAPER SERIES

\title{
QUASI-EXPERIMENTAL EVIDENCE ON THE EFFECTS OF UNEMPLOYMENT INSURANCE FROM NEW YORK STATE
}

\author{
Bruce D. Meyer \\ Wallace K. C. Mok \\ Working Paper 12865 \\ http://www.nber.org/papers/w12865 \\ NATIONAL BUREAU OF ECONOMIC RESEARCH \\ 1050 Massachusetts Avenue \\ Cambridge, MA 02138 \\ January 2007
}

*Contact Bruce D. Meyer, bdmeyer@uchicago.edu, Harris School of Public Policy Studies, University of Chicago, 1155 E. 60th Street, Chicago, IL 60637. We would like to thank Joyce Burnette and Uri Kogan for outstanding research assistance, John Comiskey of the New York State Department of Labor for supplying the data, and Joseph Altonji, Raj Chetty, John Ham, Robert Fairlie, Paula Worthington and seminar participants at the Institute for Research on Poverty, Northwestern University, the NBER Summer Institute, the University of Chicago and the Federal Reserve Bank of Chicago for their comments. We are grateful to the National Science Foundation, the Searle Fund and the Stigler Center for their support. The views expressed herein are those of the author(s) and do not necessarily reflect the views of the National Bureau of Economic Research.

(C) 2007 by Bruce D. Meyer and Wallace K. C. Mok. All rights reserved. Short sections of text, not to exceed two paragraphs, may be quoted without explicit permission provided that full credit, including (C) notice, is given to the source. 
Quasi-Experimental Evidence on the Effects of Unemployment Insurance from New York State

Bruce D. Meyer and Wallace K. C. Mok

NBER Working Paper No. 12865

January 2007

JEL No. J64,J65

\begin{abstract}
$\underline{\text { ABSTRACT }}$
This paper examines unemployment duration and the incidence of claims following a 36 percent increase in the maximum weekly benefit in New York State. This benefit increase sharply increased benefits for a large group of claimants, while leaving them unchanged for a large share of claimants who provide a natural comparison group. The New York benefit increase has the special features that it was unexpected and applied to in-progress spells. These features allow the effects on duration to be convincingly separated from effects on incidence. The results show a sharp fall in the hazard of leaving UI that coincides with the increase in benefits. The evidence is also consistent with a substantial effect of the benefit level on the incidence of claims and with this change in incidence biasing duration estimates. The evidence further suggests that, at least in this case, standard methods that identify duration effects through nonlinearities in the benefit schedule are not badly biased.
\end{abstract}

Bruce D. Meyer

Harris School of Public Policy

University of Chicago

1155 E. 60th Street

Chicago, IL 60637

and NBER

bdmeyer@uchicago.edu

Wallace K. C. Mok

Department of Economics

Northwestern University

Evanston, IL 60208

w-mok@comcast.net 


\section{Introduction}

Breaking a longstanding deadlock, legislative leaders and Gov. Mario M. Cuomo agreed today to increase New York State's maximum unemployment benefit by 36 percent, the first raise in five years. Under the plan, which was quickly approved by both houses of the Legislature, the maximum weekly benefit of $\$ 180$ will immediately rise to $\$ 245$.

New York Times, April 12, 1989, p. B1.

The effect of unemployment insurance (UI) on unemployment is of interest for two main reasons. First, many authors have argued that UI is a major determinant of differences in unemployment across countries and over time. ${ }^{1}$ Second, the magnitude of the effect of UI on unemployment is a key input into optimal UI benefit calculations. ${ }^{2}$ A large literature has examined the effects of UI on unemployment. ${ }^{3}$ However, the validity of the sources of identification used in much of the literature has not been carefully examined. Most work on UI identifies its effects through cross-state variation in benefits or by assuming a linear relationship between earnings and duration. Thus, the work requires the comparability of different states or requires strong functional form assumptions. Sometimes changes over time within a state are used as an additional source of variation. ${ }^{4}$ This paper continues an approach to identification that examines data from before and after sharp changes in the generosity of UI payments. This quasiexperiment or natural experiment approach follows the methods begun by Classen (1981), Solon

${ }^{1}$ See Layard, Nickell, and Jackman (1991) and Ljungqvist and Sargent (1998), for example.

${ }^{2}$ Baily (1977), Gruber (1997), and Chetty (forthcoming) pursue this approach.

${ }^{3}$ Detailed surveys can be found in Meyer (2002), Holmlund (1998), Atkinson and Micklewright (1991), Danziger, Haveman, and Plotnick (1981), Gustman (1983), Hamermesh (1977), and Welch (1977).

${ }^{4}$ See Moffitt (1985), Meyer (1990), and Gritz and MaCurdy (1989) for example. 
(1985) and Meyer (1989). ${ }^{5}$ This paper examines the effects of a 36 percent increase in the maximum UI benefit in New York State on the incidence and duration of UI claims.

Several aspects of the New York reform make it particularly suitable for examination. First, the benefit increase was unexpected. A benefit increase had been prevented in the past because of a procedural deadlock in the Legislature. ${ }^{6}$ After the announcement of an agreement between the legislative leaders and the governor, the reform was passed in a few hours and took effect six days later. Second, because the procedural deadlock had previously prevented a benefit increase, the increase is unlikely to have been caused by economic conditions in the state. Third, unlike most UI benefit increases, the higher benefits were available to those who had started their claims before the increase became effective. Thus, we can examine the effect of the higher benefits on the durations of a pool of claimants whose decision to file could not have been influenced by the higher benefits. Finally, unemployment was fairly stable in New York State during this time period and the state is large enough that we can disaggregate results by industry and sub-state region.

The difficulty of identifying UI effects occurs in its most extreme form within a single state at a point in time. The weekly UI benefit is a constant fraction of previous earnings except when an individual receives the minimum or maximum weekly benefit. Since previous earnings strongly influence the payoff from returning to work, the economic benefits of returning to work and the economic gains from receiving benefits are each largely influenced by a common variable, previous earnings. Regressions of spell length on weekly benefits and previous

\footnotetext{
${ }^{5}$ Subsequent papers using a "natural experiment" or "quasi-experimental" method include Hunt (1995), Card and Levine (2000), Carling, Holmlund and Vejsiu (2001), and Roed and Zhang $(2003,2005)$.

${ }^{6}$ The New York Times reported that: "The New York increase, however, was held up because negotiators in the Legislature had until recently insisted on tying that issue to discussion of increases in workers compensation benefits. It was only after the two were severed that the way to a vote was cleared."
} 
earnings consequently cannot easily distinguish between the effect of UI and the highly correlated influence of previous earnings. Identification is impossible without a functional form assumption on the relationship between previous earnings and spell length. ${ }^{7}$

A key idea behind this study is illustrated by Figure 1. Figure 1 displays the schedule relating the UI weekly benefit amount (WBA) in New York to previous average weekly earnings. The schedule is typical of those in the other states. The solid line is the schedule prior to the April 17, 1989 increase in the maximum weekly benefit amount. The dashed line is the revision to the schedule due to the benefit increase. Between the minimum and the maximum, the weekly benefit amount is one-half of previous weekly earnings. The UI reform increased the benefits received by the High Earnings group with previous weekly earnings greater than $\mathrm{E}_{3}$, and increased the benefits of the Medium Earnings group with earnings between $\mathrm{E}_{2}$ and $\mathrm{E}_{3}$. But, the Low Earnings group, with earnings between $\mathrm{E}_{1}$ and $\mathrm{E}_{2}$, was unaffected by the change. These Low Earnings individuals provide a natural comparison group to capture changes over time common to all individuals in the state. By comparing changes in spell lengths and the number of claims before and after the benefit increase for these three groups, we estimate the effects of higher benefits.

The New York benefit increase was unexpected and applicable to all weeks claimed after April 17, 1989 regardless of when an individual filed for benefits. This unusual aspect of the change allows us to examine the effect of benefits on those who had filed just prior to the increase and for whom the increase was unexpected. Thus, we can separate the effect of higher benefits on duration from its effect on the composition of the pool of claimants who start spells. There is only a small literature on the effect of benefit generosity on UI take-up, but research indicates that between one-quarter and one-half of the unemployed eligible for benefits have not

\footnotetext{
${ }^{7}$ This identification problem created by the dependence of program generosity on an individual's previous earnings is common to many social insurance programs and is emphasized in Krueger and Meyer (2002). See Meyer, Viscusi and Durbin (1995) for a similar paper on workers' compensation.
} 
filed in recent years. ${ }^{8}$ Corson and Nicholson (1998) and Blank and Card (1991) estimate the effect of the weekly benefit amount on UI take-up rate and find elasticities of 0.2 to 0.6 in aggregate Current Population Survey state by year data. Blank and Card find no significant effect in Panel Study of Income Dynamics micro data. McCall (1995) finds elasticities that range from 0.26 to 0.35 in microdata. Anderson and Meyer (1997) using administrative data from the Comprehensive Wage and Benefit History project and find benefit amount elasticities ranging from about 0.4 to nearly 1.0 .

Since the benefits of filing for UI depend on a person's expected duration of unemployment, one might expect those who enter the UI pool when benefits rise to be different from those who currently receive benefits. It is unlikely that available explanatory variables would be able to account for this tendency, as they explain only a tiny fraction of variation in durations. No previous study has been able to examine the effect of benefits on the duration of UI claims without possible bias due to changes in the pool of claimants. One might believe that endogenous takeup would necessarily lead duration elasticities to be biased downward. However, as the model below clearly shows, this may not be the case. Intuitively, those who do not apply for benefits are likely those with shorter expected (and on average actual) durations. However, those among the pool of initial non-applicants who are most likely to be induced by a benefit increase to apply are those who would receive the most from the increase, i.e. those who expect to have a long duration and thus receive that higher benefit for many weeks. Thus, the bias in the duration elasticity could be upward.

There are drawbacks to examining one state over a two-year period. There may be important macroeconomic changes during the period. The techniques used in the paper remove any bias if such changes affect the different earnings groups equally. However, if changes in the macroeconomy affecting unemployment are peculiar to the High and Medium Earnings groups, then biases would result. Most macroeconomic shocks are thought of as shocks to particular

\footnotetext{
${ }^{8}$ See Blank and Card (1991) and Vroman (1991).
} 
industries or regions. Therefore, we look within industries and regions in New York to see if similar patterns emerge. Fortunately, New York State is large enough for these sub-state analyses.

\section{The New York State UI Law and the Data}

This section describes the main characteristics of New York State's UI law and the data used in the study. To qualify for UI, an individual had to have worked at least 20 weeks out of the preceding 52 and have earned an average of at least 80 dollars during those weeks worked. ${ }^{9}$ The weekly benefit paid after a one week waiting period was 50 percent of average weekly earnings, so that the minimum weekly benefit was $\$ 40$. The maximum weekly benefit was originally $\$ 180$ and increased to $\$ 245$ on April 17, 1989. The maximum weekly benefit rose again on April 16, 1990 to $\$ 260$. The potential duration of benefits was a uniform 26 weeks during the period examined.

The individual claim data used in the study come from separate data files for 1988 and 1989 which include all UI recipients who began claims in those years. The number of days of benefits received is recorded, as well as age, sex, race, education, the 4-digit SIC of the previous employer, the week the claim was filed, previous earnings and weeks worked, and the 5-digit zip code of the claimant. Close to one-half million claims are available for each year.

We asked the New York State Department of Labor to delete some classes of observations from the tapes on which we perform most analyses. Claims from firms with mass layoffs during the year are dropped, as are claims from firms with extended strikes. These deletions were made because strikes might unduly influence the results and individual

\footnotetext{
${ }^{9}$ A provision which applied to less than one percent of claims allowed eligibility for those who worked 15 weeks over the last 52 weeks with a weekly wage of at least $\$ 80$ and who worked at least 40 weeks in the last 104 weeks with at least $\$ 3,200$ in total earnings during those 40 weeks.
} 
observations from mass layoffs or strikes cannot be taken as independent in either incidence or duration calculations. In New York, workers on strike are eligible for UI benefits after eight weeks. An examination of Current Wage Developments reveals only three work stoppages involving 1,000 or more workers in New York during the sample period. Observations from these firms are deleted including 32,000 NYNEX Corporation workers who were on strike from August 6 to December 4 of 1989. Observations from firms with mass layoffs according to the BLS definition are also excluded. The BLS defines a mass layoff to be a layoff of at least 31 days duration, involving 50 or more individuals who filed initial claims for UI during a consecutive 3-week period. ${ }^{10}$ The exclusion of mass layoff data is based partly on the value of the dependent variable, so it likely induces a small amount of bias in duration estimates. ${ }^{11}$ In all, the strike and mass layoff exclusions reduce the 1988 sample from 476,173 to 454,169 and the 1989 sample from 581,881 to 519,846 .

\section{A Model of UI Takeup and Biases in Duration Elasticities}

This section provides a theoretical model of the takeup decision and discusses some of its implications. ${ }^{12}$ In particular, we show how endogenous takeup can bias estimates of the benefit effect on unemployment duration. We suppose that a potential applicant maximizes expected utility, which is taken to be a function of income and the stigma or transaction costs of applying for UI. The worker weighs these costs of applying against the benefits, which are determined

\footnotetext{
${ }^{10}$ See U.S. Department of Labor $(1989,1990)$ for tabulations of mass layoffs by industry and time period.

${ }^{11}$ The changes in duration and incidence are very similar in the first two quarters if these exclusions are not made. For the last two quarters, the main change is that 32,000 striking workers from NYNEX Corporation are deleted.

${ }^{12}$ The effects of UI on unemployment duration are well known, so we do not explicitly discuss them here. See Meyer (2002) for references.
} 
primarily by the level and duration of benefits and the distribution of possible spell lengths that the worker believes she faces. This emphasis on expected spell length is motivated by the large fraction of nonapplicants who indicate the they do not apply because they expect a short spell. Table 1 in Anderson and Meyer (1997) reports that 37 percent of those who believe that they are eligible and do not apply indicate that they do not apply because they expect to get another job soon or be recalled. The next most common reasons (besides "other" and "don't know") are "too much work/hassle to apply" at under 7 percent and "too much like charity/welfare" at under 6 percent.

Formally, let the utility of income y be $\mathrm{U}(\mathrm{y})$ for a non-applicant and $\mathrm{U}(\mathrm{y})$-c for an applicant. For simplicity, the period is length one, the length of unemployment is $\lambda$, and the potential duration of benefits is $\mathrm{d}$. The wage is $\mathrm{w}$ and the unemployment benefit is $\mathrm{b}$. Assume that a potential applicant takes the cumulative distribution of unemployment spell lengths that she could experience to be $F(\lambda)$. Finally, assume that the application cost varies across individuals so that $\mathrm{c}=\mathrm{C}+\epsilon$, where $\epsilon$ is a continuously distributed random variable, with c.d.f. $\mathrm{L}$. The expected utility of an individual who does not apply is

(3.1) $\int_{0}^{1} U(w(1-\lambda)) d F(\lambda)$,

while the expected utility of an applicant is

$$
\begin{gathered}
\int_{0}^{d} U(w(1-\lambda)+\lambda b) d F(\lambda)+\int_{d}^{1} U(w(1-\lambda)+d b) d F(\lambda)-C-\epsilon \\
=\int_{0}^{1} U(w(1-\lambda)+b \min \{d, \lambda\}) d F(\lambda)-C-\epsilon
\end{gathered}
$$

An individual decides to apply if the benefits exceed the costs, i.e. if

$$
\int_{0}^{1}[U(w(1-\lambda)+b \min \{d, \lambda\})-U(w(1-\lambda))] d F(\lambda)>C+\epsilon
$$


The implied probability of applying for UI is thus

$$
P=L\left(\int_{0}^{1}[U(w(1-\lambda)+b \min \{d, \lambda\})-U(w(1-\lambda))] d F(\lambda)-C\right)
$$

The effects of changes in the key individual and program characteristics can be determined by differentiating this probability. Higher UI benefits raise the takeup probability, while lower application costs increase the probability of application. A marginal increase in the potential duration of benefits increases the probability, but only if the potential applicant believes she may be unemployed at least as long as the potential duration. An increase in the wage decreases the application probability as long as $U^{\prime \prime}$ is negative. One can also show that rightward shifts in the distribution of expected unemployment spell lengths will increase the application probability.

With a few simplifications, this framework can also be used to determine how a change in the weekly benefit amount would affect the spell length composition of the pool of applicants. This derivative is important because it determines the bias in estimates of the elasticity of mean spell duration with respect to the weekly benefit from samples of claimants. Previous work has often argued that endogenous takeup implies that duration elasticities are biased downward, since non-claimants generally have shorter spells than claimants. The following example shows that marginal non-claimants may very well have longer spells than claimants so that the sign of the bias is indeterminate.

For simplicity, assume that utility is linear so that $U "=0$. Also assume that there are two equally common types of individuals with known spells lengths $\lambda_{1}$ and $\lambda_{2}$, both less than $d$, and that benefits have no effect on the duration of claims. The mean spell length of applicants is now (3.5) $\bar{\lambda}=\lambda_{1} \frac{L_{1}}{L_{1}+L_{2}}+\lambda_{2} \frac{L_{2}}{L_{1}+L_{2}}$, where $L_{1} \equiv L\left(b \lambda_{1}-C\right)$ and $L_{2} \equiv L\left(b \lambda_{2}-C\right)$. 
The mean duration of spells of claimants may increase or decrease with the level of UI benefits. Without loss of generality, assume $\lambda_{1}>\lambda_{2}$. Then

$$
\frac{\partial \bar{\lambda}}{\partial b} \text { has the same sign as }\left(\lambda_{1} L_{1}{ }^{\prime} / L_{1}-\lambda_{2} L_{2}{ }^{\prime} / L_{2}\right), \text { where } L_{1}{ }^{\prime} \equiv L^{\prime}\left(b \lambda_{1}-C\right) \text { and } L_{2}{ }^{\prime} \equiv L^{\prime}\left(b \lambda_{2}-C\right)
$$

The intuition for this result should be pretty clear. The outcome depends on the proportionate change in the number of new claims among those with long spells relative to that for those with short spells. $\lambda_{\mathrm{i}} \mathrm{L}_{\mathrm{i}}^{\prime}$ is the marginal change in new claims of type $\mathrm{i}$, and dividing by $\mathrm{L}_{\mathrm{i}}$ puts it in proportionate terms. More simply, the indeterminate sign occurs because an increase in the weekly benefit amount has a greater effect on those who expect to be unemployed a long time and thus expect to collect the higher weekly benefit for many weeks. This tendency can offset the fact that a larger share of those who expect long spells will have already claimed. The implication of this result is that endogenous takeup could bias unemployment duration estimates in either direction. ${ }^{13}$

The model above assumed that an individual makes a one-time decision at the start of unemployment as to whether or not to file for UI. Solon (1981), citing prior work by Ehrenberg, Hamermesh and himself suggests a different argument. In studies that use the duration of UI claims, it may be that higher benefits induce a person to file more quickly, but do not effect the time out of work. Either this argument, or the one outlined above provide a reason that one may want to obtain an estimate of duration effects of UI that is not potentially biased by an effect of benefits on claim filing.

\footnotetext{
${ }^{13}$ Since our model can be applied to durations on other social insurance program where the generosity of the program and expected duration affect participation, the result of indeterminate bias also applies to programs such as AFDC and workers' compensation.
} 


\section{Economic Conditions in New York State}

This section provides some background statistics on the New York State labor market around the time of the benefit increase. As this paper examines data from 1988 and 1989, it is important to describe economic conditions at the time of the increase in UI benefits. Table 1 reports monthly data on employment and unemployment for the 1988-1990 period. Throughout this period, the unemployment rate is quite low, averaging 4.2, 5.1, and 5.2 respectively in the three years. Employment rises by about 100,000 in each of 1988 and 1989 and then falls back to its earlier level by the end of 1990. During the period on which we primarily focus, the first two quarters of 1988 and 1989, unemployment is almost 1 percentage point higher in the second year, while employment is over 1 percent higher. These patterns can be seen visually in Figure 2 which graphs the monthly employment level and the unemployment rate for 1988-1990.

Employment patterns by industry and region are a bit more complex. Table 2 reports employment by broad industry group. None of the industries have pronounced secular increases or decreases in employment. Employment in Durable and Nondurable manufacturing does decline somewhat, while the other industries tend to show increases. The bottom several lines of the table report measures of volatility or dispersion of industry level quarterly employment. We report the coefficient of variation of industry level employment measured in levels and logarithms. We also report the variance of the residuals of log employment after regressing it on a constant and a time trend. In these statistics construction sticks out as being much more variable over time than any industry. In fact, the variance of the detrended residuals for construction is more than fifteen times that of the closest other industry. This volatility of the construction industry motivates our focus through much of the rest of the paper on a nonconstruction sample. 
Appendix Table 1 reports average monthly employment by sub-state region within New York. ${ }^{14}$ Due to changes in the benchmarks used in the data, the most valid comparisons can be made between an April to October average for 1988 and 1989. Over this period, employment rises 1-2.5 percent in all regions except Nassau-Suffolk PMSA, Poughkeepsie and Binghampton which have stable or declining employment.

\section{Descriptive Statistics on Incidence and Duration}

To assess the effects of the benefit increase, we begin by reporting incidence and duration numbers by quarter and earnings group. The statistics of most interest are the first quarter duration statistics, and the second through fourth quarter incidence statistics. The first quarter duration numbers could not have been affected by changes in the pool of recipients, as UI claimants did not know about the increase at the time they filed for benefits. Increases in duration for these claimants cannot be attributed to changes in the claimant pool, and may be attributable to the benefit increase. Almost all of the second, and all of the third and fourth quarters of 1989 took place after the benefit increase, so these quarters should be examined for changes in claim filing after the increase.

Table 3 reports the incidence and duration of UI claims by quarter for the 1988 and 1989. ${ }^{15}$ We report separate estimates for the three earnings groups defined in Section 1 and Figure 1. The three groups are the High Earnings group, whose members experienced the full

\footnotetext{
${ }^{14}$ The numbers reported are for the 10 largest areas within New York state which included 88.8 percent of employment in 1988.

${ }^{15}$ These tabulations exclude observations with no previous earnings, with weeks worked less than 20 or real weekly earnings less than $\$ 80$. We also exclude the .3 percent of observations with pension reductions in benefits to avoid the complications they would add. These exclusions eliminate 2.8 percent of observations in 1988 and 2.0 percent in 1989 . We also exclude those who worked in the construction industry, which is a further 16.2 percent of observations in 1988 and 16.8 percent of observations in 1989.
} 
effect of the benefit increase after April 17, 1989, the Medium Earnings group which received on average less than half of the increase of the High Earnings group, and the Low Earnings group whose benefits were unchanged by the UI reform. The brackets for these earnings groups are indexed using average weekly earnings in New York. ${ }^{16}$

For each quarter, we report the ratio of the number of claims in the two years and the difference in the average number of weeks of benefits received in the two years. At the bottom of the upper panel, we also report the change in incidence for the High and Medium earnings groups relative to the Low earnings group. At the bottom of the lower panel, we report the differences-in-differences for duration, comparing the changes for the High and Medium earnings groups to those for the Low earnings group in each quarter.

Several patterns are evident in the data. First, there is a pronounced seasonality to both the incidence and duration of claims. Incidence is lowest in the second quarter for all earnings groups and both years. Duration is longest in the second and fourth quarters for all earnings groups and both years. The pronounced seasonality is the reason for comparing the different calendar quarters of 1989 to the same quarter in the previous year.

There are only moderate changes in incidence for all of the earnings groups in the first quarter (though the changes are significantly different from zero), but large changes in later quarters. In the first quarter, the High and Medium Earnings groups experience a 3-5 percent fall in the number of claims, while Low Earnings incidence rises by 1 percent. The roughly stable pattern of incidence for the first quarter of 1989 relative to 1988 is another reason we focus on this quarter in subsequent duration analyses. There are large changes in incidence during the other quarters, particularly quarters three and four. In those quarters High Earnings claims rise 40 percent while Medium and Low claims rise about 20 and 15 percent, respectively. These

\footnotetext{
${ }^{16} \mathrm{E}_{1}, \mathrm{E}_{2}$ and $\mathrm{E}_{3}$ in Figure 1 have been indexed using the annual change in average weekly earnings of employees covered by the New York State UI law over 1987-1989, which was 5.3 percent and was supplied by the New York State Department of Labor. Precisely, $\mathrm{E}_{1}, \mathrm{E}_{2}$ and $\mathrm{E}_{3}$ are taken to be 80,360 , and $490 / 1.053$ in 1988 , respectively, and $80 * 1.053,360 * 1.053$, and 490 in 1989.
} 
changes are highly statistically significant as the standard errors are always less than 1.5 percent and often smaller. These numbers are consistent with large effects of the higher benefits on the relative incidence of claims. The implied incidence elasticities for the $3^{\text {rd }}$ quarter are 0.95 and 0.86 for the High and Medium Earnings groups. For the $4^{\text {th }}$ quarter they are 0.73 and -0.09 , respectively. There is a possibility that these numbers could be due to macroeconomic shocks to industries or regions that are disproportionate employers of High and Medium Earnings workers. We show below that such shocks are not the explanation as the above patterns hold within substate region and industry.

The durations numbers are also consistent with UI benefit effects. There is a large increase in mean duration of UI receipt in the first quarter for all earnings groups. The changes between 1988 and 1989 are larger for the High and Medium Earnings groups. If one subtracts off the change for Low Earnings individuals, the High and Medium changes are 0.66 and 0.11 weeks with standard errors of 0.10 and 0.12 respectively. Thus the increase in benefits appears to be associated with an increase in weeks of UI receipt. One can scale these increases to arrive at elasticities after making several assumptions. High Earnings individuals in the first quarter are affected more by the benefit increase if their spell began closer to when benefits rose. We calculate an average benefit for someone receiving 20 weeks of continuous benefits following the claim week. We use 20 weeks because the mean duration is about 16 weeks, but many individuals' period of receipt is likely interrupted by periods when they do not receive UI. ${ }^{17}$ Using these assumptions, we calculate elasticities of mean duration with respect to the average benefit of 0.41 for High Earnings individuals and 0.26 for Medium Earnings individuals. ${ }^{18}$

\footnotetext{
${ }^{17}$ The total weeks of benefits received in the benefit year may come from several spells. Often benefits are received over a longer calendar period than the number of weeks of UI receipt.

${ }^{18}$ The percentage increases in benefits for the High, Medium and Low groups are 12.6, 4.2 and 1.6 percent respectively in the first quarter. They are approximately 29.1,13.2 and 0 percent in the other three quarters.
} 
The second quarter has patterns similar to those of the first, while a very different view of duration effects would be obtained from looking at the third and fourth quarters. In these last two quarters the duration of High Earnings claims falls relative to those of Low Earnings individuals. One should note though, that the increased relative incidence of High Earnings claims may be associated with changes in composition of the pool of claimants. The data from the third and fourth quarter may provide a good example of the biases that can arise in duration estimates when the effects of benefits on incidence are ignored. This possibility of bias in duration estimates when incidence is ignored was one of the key implications of the model of Section 3.

Since the principal puzzle in Table 3 is the shorter durations in the third and fourth quarters for High Earnings claims, we further investigated evidence for a change in the composition of claims in these quarters. ${ }^{19}$ For all four quarters and three earnings groups, we predict durations in 1989 using a linear model estimated for that earnings group and quarter in 1988. We predict durations using base year earnings, weeks worked in the base year, age, gender, race, education, industry and region. Table 4 reports the mean predicted duration from these models along with the mean predicted duration for 1988 (which equals the actual mean duration). We focus on observable characteristics of claimants with the presumption that observable and unobservable characteristics will move in the same direction (see Altonji, Elder and Taber 2005 for a discussion of a stronger version of this assumption).

We find that predicted durations change very little in the first quarter. High earnings predicted durations change less than 0.05 of a week between 1988 and 1989. This result may be expected since there was little change in the incidence of claims. On the other hand, after the benefit increase, in the third and fourth quarters when High Earnings claims increase sharply (but durations fall) we see that the observable characteristics of claimants have shifted sharply in the direction of those that tend to have shorter spells. Mean predicted duration falls for the third

\footnotetext{
${ }^{19}$ We thank Julie Cullen for suggesting that we pursue this idea.
} 
quarter by three-quarters of a week, while fourth quarter predicted mean duration falls by more than one-third of a week. This result is consistent with endogenous takeup and the changed composition of claims being responsible for the counterintuitive drop in spell length for High Earnings claimants in the third and fourth quarters.

We should also point out that the standard errors on changes in incidence and duration are likely understated because observations that are part of large layoffs and recalls are not truly independent. There may also be shocks that we cannot account for which are common to all High or Medium Earnings individuals during a quarter.

To assess if macroeconomic shocks to particular regions or industries could have caused the changes in incidence and duration, we also examine the same statistics within regions and industries. For this analysis we group the 4 smallest regions together, to obtain 7 areas for which we can obtain reasonably precise numbers. In 6 of 7 regions, the High Earnings claims have larger increases in duration than the Low Earnings claims in the first quarter. In the third and fourth quarters, all 7 regions experience larger increases in the incidence of claims for High Earnings individuals than Low Earnings individuals, and 5 out of 7 do in the second quarter.

Within industry, the patterns of Table 3 are also fairly strong. 6 of the 7 largest industries (in terms of first quarter UI claims) had larger increases in first quarter duration for the High Earnings group than the Low Earnings group. The incidence changes in the later quarters were even more widespread, with all 7 showing relative increases for the High Earnings group compared to the Low Earnings group in the third and fourth quarters. Thus, the changes in incidence and duration by previous earnings group are widespread and not due to shocks to particular industries or regions.

\section{Regression Estimates of Duration}

The within region and industry analyses above suggest that changes in the composition of the pool of UI claimants along these dimensions were not responsible for the increase in 
duration. However, there are other characteristics of claimants that may have affected the changes in duration such as age, education, race and previous earnings. We want to control for all of these characteristics at once. This section reports regression equations for the duration of UI claims which control for a large number of individual characteristics. We begin by estimating equations that are the regression analog of differences-in-differences with controls. The specifications that we estimate are variants of the equation:

$$
\begin{aligned}
& \ln (\text { duration })=\alpha+\beta_{1} \text { After Increase*High Earnings }+\beta_{2} \text { After Increase*Medium Earnings } \\
& +\beta_{3} \text { After Increase }+\beta_{4} \text { High Earnings }+\beta_{5} \text { Medium Earnings } \\
& +\beta_{6} \ln (\text { previous weekly earnings })+\beta_{7} \ln (\text { previous weeks worked })+\gamma^{\prime} X+\epsilon
\end{aligned}
$$

where $\ln$ (duration) is the $\log$ of duration in days, ${ }^{20}$ After Increase, High Earnings, and Medium Earnings are indicator variables for being after the increase, in the high earnings group, and in the medium earnings group, respectively. The vector $\mathrm{X}$ includes age, sex, education, race, industry and sub-state region. Depending on the exact specification, $\mathrm{X}$ may also include indicator variables for the week the spell began and additional interactions.

Table 5 reports the results from the regression estimates. In all specifications, the sample is the first quarter data. ${ }^{21}$ Specifications (1) and (2) are the regression analogs of differences in differences that are variants of equation (6.1). Specification (2) replaces the After Increase, High Earnings and Medium Earnings indicators with their interactions with a full set of indicator variables for the week of the year a UI spell began (12 indicator variables). The coefficients on After Increase interacted with High Earnings $\left(\beta_{1}\right)$ and Medium Earnings $\left(\beta_{2}\right)$ are very similar to

\footnotetext{
${ }^{20} \mathrm{We}$ set durations of zero equal to 0.5 for this set of analyses.

${ }^{21}$ The regressions drop observations with missing age, sex, race, education, earnings or industry. They also drop out of state claims which by itself excludes 7.2 percent of the observations. Including the exclusions of Section 5, 20.8 percent of the 1988 observations and 12.7 percent of the 1989 observations are dropped (mostly due to missing education).
} 
the estimates obtained by taking logs of the numbers in Table 3 and subtracting the Low Earnings numbers from the Medium and High numbers. This similarity suggests that changes in observable individual characteristics in this sample are not very important (as was also found in Section 5). High Earnings durations rise about 8 percent, while Medium Earnings durations do not appreciably change. The coefficient on the High Earnings group after the increase is strongly significant.

We also estimate specifications where the key explanatory variables are functions of the weekly UI benefit amount. We measure the benefit increase using a variable which is the average benefit that a claimant would receive during a 20 continuous week claim beginning after the filing week (see Section 5 for a discussion). We can compare the coefficient on this variable to that on a conventional benefit variable identified by the nonlinear relationship between benefits and previous earnings. These specifications are of the form:

(6.2) $\ln ($ duration $)=\alpha+\beta_{1}[\ln ($ average new benefit $)-\ln ($ old benefit $)]+\beta_{2} \ln ($ old benefit $)$

$+\beta_{3}$ After Increase $+\beta_{4}$ High Earnings $+\beta_{5}$ Medium Earnings

$+\beta_{6} \ln ($ previous weekly earnings $)+\beta_{7} \ln ($ previous weeks worked $)+\gamma^{\prime} X+\epsilon$.

The first variable is the logarithm of the average weekly benefit a claimant would receive under the new law during a 20 week claim minus the logarithm of the benefit under the old law. This variable captures the change in the weekly benefit amount with the new law. The second variable is the $\ln$ (old benefit) which is the logarithm of weekly benefits under the old UI law. It is separately identified from previous earnings through the kink in the benefit schedule at $\mathrm{E}_{2}$ in Figure 1. As both variables are in logarithms, their coefficients can be interpreted as elasticities. Specifications (3) through (6) in Table 5 are variants of this equation.

The estimates of the two benefit coefficients $\left(\beta_{1}\right.$ and $\left.\beta_{2}\right)$ are fairly similar across the different specifications and are similar to each other. The coefficient on the old benefit is always 
0.26. The coefficient on the change in the benefit amount varies from 0.23 to 0.42 . A test of the restriction $\beta_{1}=\beta_{2}$ fails to reject in all of the specifications. A few of the specifications are particularly noteworthy. Specification (4) replaces the After Increase indicator with a set of indicator variables for each of the possible weeks a spell could have begun. Specification (5) allows interactions between the 19 region and 10 industry dummies and the dummy variable for being after the increase. Thus, this specification allows for shocks to industries and regions after the increase that are common to all earnings groups. The coefficient on the benefit increase variable is very similar to that in the other specifications. Specification (6) includes interactions between being after the increase and in the High and Medium Earnings groups as well as including the two benefit variables. Through Specification (5), the change in benefit coefficient is strongly significant, while in Specification (6) the coefficient falls somewhat and is no longer significant, largely due to a doubling of the standard error. It also appears that the change in duration for the High Earnings group in 1989 is not fully captured by the average benefit variable as the coefficient on After Increase*High Earnings is positive and significantly different from zero.

Because durations are limited to be between 0 and 26 weeks, we also estimated Tobit models which account for both this left and right censoring. These specifications are reported in Table 6. The Tobit coefficients tend to be quite a bit larger than the linear regression estimates. This result is not that surprising given that the Tobit coefficients can be interpreted as the effect on underlying unemployment duration rather than the potentially censored weeks of UI receipt. The benefit elasticities from the dummy variable coefficients are close to 0.5 while the $\ln (\mathrm{WBA})$ specifications suggest higher elasticities. The change in $\ln (\mathrm{WBA})$ coefficients imply elasticities of between 0.6 and 0.7 , while the benefit coefficients identified through the bend in the schedule suggest elasticities of around 0.4. A test of the restriction $\beta_{1}=\beta_{2}$ fails to reject in most specifications, though it does reject in the case of specification (4). The final specification in 
Table 6 indicates that it is difficult to separate out the effect of the change in the weekly benefit from indicators for the groups that received the benefit increase.

\section{Hazard Model Estimates of Duration}

Hazard models provide a sensible way to account for two key features of the data. First, durations are both left censored at zero and right censored at 26 weeks as discussed above. Second, the level of the weekly UI benefit amount varies over the course of a spell for those who filed shortly before the April 1989 benefit increase (and are in the Medium or High Earnings groups). Hazard models easily incorporate these two features of the data. We estimate a series of specifications for the hazard of leaving UI as a function of measures of time, the UI benefit, and individual characteristics. Formally, let $\mathrm{T}_{\mathrm{i}}$ be the length of individual i's period of UI receipt. Then the hazard for individual $i$ at time $t, \lambda_{i}(t)$, is defined by the equation,

$\lambda_{i}(t) \equiv \lim _{h \rightarrow 0^{+}} \frac{\operatorname{Prob}\left[t+h>T_{i} \geq t \mid T_{i}>t\right]}{h}$.

Before estimating parametric models, we plot the hazard rate of those in the High Earnings group and that of the Low Earnings group for comparison using the weekly hazard derived from daily data. The top panel of Figure 3 shows this pattern for 1988, while the bottom panel displays the 1989 pattern. In 1988 the High and Low Earnings groups have almost identical hazards. In 1989, after the increase in benefits in the $16^{\text {th }}$ week for those in the High Earnings group, there appears to be a fall in the hazard of those in the High Earnings group relative to that for the Low Earnings group. This pattern accords with the expected decline in the departure rate from the UI rolls after benefits have increased. 
To account for individual characteristics and economic conditions, we parameterize the hazard using a proportional hazards form, i.e. $\lambda_{i}(t)=\lambda_{0}(t) \exp \left[z_{i}(t)^{\prime} \beta\right] . \quad \lambda_{0}(t)$ is called the baseline hazard and captures how exit rates change as a spell progresses. The time varying explanatory variables $z_{i}(t)$ include the weekly benefit amount, as well as indicators for the current calendar week. Thus, we can account for the changing benefit and potentially changing conditions in the labor market in a sensible way. The vector $z_{i}(t)$ also includes time constant variables such as age, gender, education, industry, region, previous earnings and weeks worked.

Given our parameterization and weekly data, spell continuation probabilities can be written as$$
P\left[T_{i} \geq t+1 \mid T_{i}>t\right]=\exp \left[-\int_{t}^{t+1} \lambda_{i}(u) d u\right]=\exp \left[-\exp \left(z_{i}(t)^{\prime} \beta\right)^{t+1} \int_{t}^{\lambda_{0}} \lambda_{0}(u) d u\right],
$$

if $z_{i}(t)$ is constant between $t$ and $t+1$. Equation (7.1) can be rewritten as

$$
P\left[T_{i} \geq t+1 \mid T_{i}>t\right]=\exp \left[-\exp \left(z_{i}(t)^{\prime} \beta+\gamma(t)\right)\right], \text { where } \gamma(t)=\ln \left[\int_{t}^{t+1} \lambda_{0}(u) d u\right]
$$

A likelihood function can then be constructed from terms like (7.2) and one minus the probability in (7.2) as in Meyer (1990).

The first set of hazard model estimates is reported in Table 7. Appendix Table 2 provides the means by period and earnings group for the covariates that are included in the models (variable definitions are provided in the Data Appendix). These specifications include a dummy variable for the week in question being after the benefit increase (After $16^{\text {th }}$ week of 1989) interacted with the High Earnings or Medium Earnings group. Controls for previous earnings, previous weeks worked, age, gender, education, race, industry, region, as well as indicators for 
the calendar week and the current spell length are included. All of these specifications control for being in the High Earnings group after the benefit increase. Benefit effects are identified through the exact timing of when the benefit increase took place.

Specifications (1) and (2) do not include the Medium Earnings group. Specification (2) and (4) through (6) include indicator variables for the week the spell began. Specifications (5) and (6) include indicators for industry and region interacted with being in the year of the benefit increase.

These specifications indicate that the hazard of ending a UI claim falls by about 6 percent after the weekly benefit rises for the High Earnings group. The coefficients do not differ much across specification. As expected, there is a smaller coefficient for the Medium Earnings group, but the coefficient is only marginally significantly different from zero. The inclusion of controls for the week a spell began or the interaction of industry and region with the second year of data has little effect on the coefficients. While these specifications control for being in the High Earnings group after the increase it is a concern that the coefficient on After*High Earnings is significantly different from zero even when we are controlling for the exact timing of the benefit increase. These coefficients suggest that there is an independent effect of being in the After*High Earnings group or that our After $16^{\text {th }}$ week variable does not fully capture the benefits change. Specification (6) only includes the spells beginning in the first six weeks of the year. This sample does not seem to suffer from this problem as the coefficient on After*High Earnings is now small and not significant. This sample is also of interest for a second reason. This sample will disproportionately include those whose benefits change later in their spell and will thus emphasize changes in benefits near the end of the benefit entitlement period. Some past work has emphasized that the effect of UI on the hazard should fall with duration (see Arulampalam and Stewart 1995). This effect is a general prediction of search models, but does not necessarily hold in labor supply models of unemployment. We find little support for this 
prediction here as the coefficient estimate is slightly higher in specification (6) than in the other specifications, the opposite of what some models predict

Our final set of duration estimates is reported in Table 8. These specifications include functions of the weekly benefit amount rather than indicator variables. Precisely, these specifications include the logarithm of the weekly benefit amount in the current week minus the benefit under the old UI law as well as a variable for the weekly benefit under the old law. The first variable captures the effect of the change in the schedule due to the benefit increase, while the second variable identifies the effect of benefits through the bend in the schedule. The specifications examined are those analogous to the specifications of Table 7. In addition specification (7) is added to analyze the identification of benefit effects through the bend in the schedule.

These specifications suggest that a ten percent increase in the benefit lowers the hazard of ending a UI spell by about 3 percent. The estimates are not appreciably affected by adding controls for the week a spell began or interactions of industry and region with the year of the increase. Specifications (5) and (6) in this table also control for being in the High (and Medium) Earnings groups after the benefit increase as in Table 7. We are now identified through the exact timing of when benefits increase and by the amount that they increase. The coefficient on the change in the weekly benefit $\left(\beta_{1}\right)$ falls somewhat, but is still significantly different from zero. In specification (6) we again restrict the sample to the first half of the quarter with the coefficient on After*High Earnings again much smaller and not significantly different from zero, while the change in benefit coefficient is little altered.

In most of the specifications, the estimated effect of the benefit under the old UI law is slightly smaller than the coefficient on the change in the weekly benefit, but still strongly significant. We now more often reject the restriction $\beta_{1}=\beta_{2}$; the evidence indicates that benefit effect identified by the schedule nonlinearity is now statistically different from that identified by the benefit increase, in specifications (1), (2) and (7). We should emphasize that this former 
coefficient cannot be identified if one includes a completely flexible set of controls for prior earnings. The last specification (7) makes this clear, as the inclusion of a spline in past earnings drives the standard error on this coefficient sharply upward and the point estimate becomes implausible.

\section{Simulating Duration Elasticities}

We also convert the duration coefficient estimates into elasticities. Following equation (7.2), we can write the estimated survivor function for observation $i$ as

(7.3) $\hat{S}_{i}(t) \equiv P\left[T_{i} \geq t\right]=\exp \left[\sum_{\tau=0}^{t-1}-\exp \left(z_{i}(\tau) \hat{\beta}+\hat{\gamma}(\tau)\right)\right]=\exp \left[\sum_{\tau=0}^{t-1}-\hat{h}_{i}(\tau)\right]$, for $\mathrm{t} \geq 1$, where

$\hat{h}_{i}(\tau)=\exp \left(z_{i}(\tau)^{\prime} \hat{\beta}+\hat{\gamma}(\tau)\right)$

The average estimated survivor function then is

(7.4) $\bar{S}(t) \equiv \frac{1}{N} \sum_{i=1}^{N} \hat{S}_{i}(t)$, where $\bar{S}(0) \equiv 1$.

Predicted mean duration of UI receipt (compensated duration) and full duration are then $\sum_{\tau=1}^{26} \bar{S}_{i}(\tau)$

and $\sum_{\tau=1}^{\infty} \bar{S}_{i}(\tau)$, respectively. To calculate full duration we need to assume a value for $\hat{h}_{i}(\tau)$ for

$\tau>25$. We use the average over 0 to 25 . To simulate the effect of raising the level of UI benefits

by ten percent we can just multiply $\hat{h}_{i}(\tau)$ in $(7.3)$ by $\exp \left(0.1 \hat{\beta}_{j}\right)$ for $\tau<26$, where $\hat{\beta}_{j}$ is the estimated 
coefficient on $\ln ($ WBA in Current Week)-ln(WBA Under Old Law) from Table 8 . We estimate elasticities by dividing the change in estimated duration from this exercise by 0.1 . For the specifications in Table 8, using the first quarter of 1988 sample, the resulting elasticities are reported in the last two rows. The compensated duration elasticities range from 0.09 to 0.17 , while the total duration elasticities range from 0.12 to 0.23 . Overall, the benefit elasticity estimates are smaller than many that have been found in the literature, such as those in Moffit (1985), Meyer (1989, 1990), Classen (1979) and Solon (1985).

\section{Subsamples}

While the elasticities that we find for the overall sample are not large, there may be components of the population whose durations respond strongly to UI. In Table 9 we report coefficient estimates on the logarithm of the change in benefits for four subsamples of the data: men, women, those under 40 years of age, and those 40 and older. The specifications that we estimate are just those reported in the first six columns of Table 8, but estimated on these subsamples. The estimates differ sharply across the subsamples. The total duration elasticities for males range from 0.07 to 0.22 , while for females they are much larger, ranging from 0.36 to 0.47. Labor supply elasticities are generally found to be larger for women, and this finding may be just another example of this regularity. The total duration elasticities for those under 40, are close to zero, while those for individuals 40 and older are quite large, ranging from 0.30 to 0.46 . Since younger workers are generally thought to be more likely to be liquidity constrained, this finding does not support the notion that liquidity constraints drive the duration response to UI (Chetty 2006), though other factors could be behind the difference between younger and older workers. 


\section{Discussion and Conclusions}

This paper examines the effect of a 36 percent increase in the maximum UI benefit in New York State. The benefit increase in New York had the unusual feature that it applied to only high and medium earnings claimants and to in-progress spells. The results suggest that this increase in UI benefits led to a large increase in the number of unemployment insurance claims. However, we cannot exclude the possibility that shocks which disproportionately affected high wage workers resulted in the increases in claims among high earning workers that received the higher benefits. We are able to rule out that shocks to particular industries or regions were responsible for this result.

There is strong evidence of an effect of the benefit increase on the duration of claims. We examine differences in means, regression estimates, as well as hazard model estimates that use the exact timing and amount of the benefit increase. The estimated elasticity of claim duration with respect to the benefit is around 0.3 . This elasticty is somewhat lower that found by Classen (1979), Solon (1985) and Meyer (1989) who also examined data around changes in benefit generosity. The estimates are about in the middle of other previous estimates. We should also note that the identification of the weekly benefit effect through the bend in the benefit schedule alone yields roughly similar, though somewhat lower estimates.

We also demonstrate how endogenous UI takeup can bias estimates of the effect of the level of benefits on the mean duration of UI receipt. We show the theoretical ambiguity of the bias and the conflicting forces that lead to this result. One-year comparisons of mean duration changes in the quarters where the benefit increase was known to potential claimants and takeup could respond yields wrong signed elasticities, illustrating that the potential for bias is real. Comparisons of observable characteristics of claimants indicate that there was a change in the 
composition of claims following the benefit increase that could explain this otherwise anomalous result.

The overall elasticities that we find tend to be low. However, for some large subsamples, in particular those 40 and older and women, we find substantial elasticities. There are several factors to consider when comparing the estimates in this paper to other estimates. First, it may be that the estimates are biased because of macroeconomic shocks that disproportionately affect High Earnings claims. We have used several identification strategies including those that rely on the exact timing and amount of the benefit increase to reduce the likelihood of this possibility. Second, it may be that the effect of a given benefit increase is smaller when the level of after-tax benefits is low relative to previous earnings. Most previous work has examined UI in a period when benefits were not taxable and thus after-tax replacement rates were high. We are also primarily examining changes in benefits for the group with the lowest replacement rates, the High Earnings group. Even after the increase in benefits, the average replacement rate for this group is only 0.37 , as reported in Appendix Table 2 . Third, we capture a slightly different partial derivative than usual since the benefit increase was a surprise. Changes in savings and other responses could have not taken place. This short-run elasticity may be lower than the long-run one. ${ }^{22}$ Fourth, it may be that UI benefits have a different impact during periods of low unemployment such as New York in the late 1980's. Fifth, our first quarter duration estimates will mostly capture the effects of UI towards the end of the eligibility period. One might expect a given UI benefit increase to have a smaller impact then as suggested in Mortensen (1977) and

\footnotetext{
${ }^{22}$ The effect of a surprise increase in benefits on unemployment could be either bigger or smaller than the effect of an expected change. If workers expect a benefit increase, they might change the type of job they take, or change the care they take to avoid being laid off (much of this would appear in incidence but might affect duration through the types of composition changes the paper emphasizes). These types of changes would likely make the response to an expected increase greater than that to a surprise increase. On the other hand, if one considers savings responses to UI, an increase in benefits that is expected will lead people to save less. Thus, the difference in unemployment durations between the high and low benefit regimes would be reduced because assets would be lower in the high benefit regime, implying that high benefit durations would be shorter than they would be if assets did not change.
} 
emphasized in Arulampalam and Stewart (1995). We have tested for this hypothesis above (specification (6) in Tables 7 and 8) by examining the sample of spells starting in weeks 1-6 of the first quarter. Since the coefficient estimates from these alternative specifications are very similar to the full sample estimates, they do not support this hypothesis. 


\section{References}

Altonji, Joseph G., Todd E. Elder, and Christopher R. Taber (2005), "Selection on Observed and Unobserved Variables: Assessing the Effectiveness of Catholic Schools," Journal of Political Economy, vol. 113, pp. 151-184.

Anderson, Patricia M. and Meyer, Bruce D. (1997), "Unemployment Insurance Takeup Rates and the After-tax Value of Benefits", Quarterly Journal of Economics, vol. 112, pp. 913-938.

Anderson, P. M. and Meyer, B. D. (2000), "The Effects of the Unemployment Insurance Payroll Tax on Wages, Employment, Claims and Denials," Journal of Public Economics vol. 78, pp. 81-106.

Arulampalam, Wiji and Mark B. Stewart (1995), "The Determinants of Individual Unemployment Durations in an Era of High Unemployment," Economic Journal vol. 105, pp. 321-332.

Baily, Martin N. 1977. "Unemployment Insurance as Insurance for Workers," Industrial and Labor Relations Review 30: 495-504.

Blank, Rebecca M. and David E. Card (1991): "Recent Trends in Insured and Uninsured Unemployment: Is There an Explanation?," Quarterly Journal of Economics, November 1991, CVI, 1157-1190.

Card, D. and Levine, P. B. (2000), "Extended benefits and the duration of UI spells: evidence from the New Jersey Extended Benefit Program", Journal of Public Economics, vol.78, pp. 107-138.

Carling, K., Holmlund, B.and Vejsiu, A. (2001), "Do Benefit Cuts Boost Job Finding? Swedish Evidence from the 1990s," Economic Journal vol. 111, pp. 766-790.

Chetty, Raj (forthcoming), "A General Formula for the Optimum Level of Social Insurance," Journal of Public Economics.

Chetty, Raj (2006), "Why do Unemployment Benefits Raise Unemployment Durations? Moral Hazard vs. Liquidity," Working Paper, University of California--Berkeley.

Classen, Kathleen P., "Unemployment Insurance and Job Search," in S.A. Lippman and J. J. McCall, eds., Studies in the Economics of Search, Amsterdam: North-Holland, 1979, ch. 10 .

Corson, Walter and Walter Nicholson, "An Examination of Declining UI Claims During the 1980's," Unemployment Insurance Occasional Paper 88-3, Washington, DC: US Department of Labor-ETA, 1988.

Danziger, Sheldon, Haveman, Robert and Plotnick, Robert, "How Income Transfer Programs Affect Work, Savings, and the Income Distribution: A Critical Review," Journal of Economic Literature, September 1981, XIX, 975-1028. 
Ehrenberg, Ronald G. and Oaxaca, Ronald L., "Unemployment Insurance, Duration of Unemployment, and Subsequent Wage Gain," American Economic Review, December 1976, 66, 754-766.

Gritz, R. Mark, and Thomas MaCurdy (1989): "The Influence of Unemployment Insurance on the Unemployment Experiences of Young Workers," Working Paper, October 1989.

Gruber, Jonathan. 1997. "The Consumption Smoothing Benefits of Unemployment Insurance," American Economic Review, 87, 192-205.

Gustman, Alan L., "Analyzing the Relation of Unemployment Insurance to Unemployment," in Ronald Ehrenberg, ed., Research in Labor Economics, Vol. 5, 1982, 69-114.

Hamermesh, Daniel S., Jobless Pay and the Economy, Baltimore: The Johns Hopkins University Press, 1977.

Holmlund, B. (1998), "Unemployment Insurance in Theory and Practice," Scandinavian Journal of Economics, vol.100, pp.113-141.

Krueger, Alan B., and Bruce D. Meyer (2002): "Labor Supply Effects of Social Insurance," in Handbook of Public Economics, Volume 4, Alan Auerbach and Martin Feldstein, eds. Amsterdam: North-Holland, 2002, 2327-2392.

Layard, Richard, Stephen Nickell, and Richard Jackman. 1991. Unemployment: Macroeconomic Performance and the Labour Market, Oxford: Oxford University Press.

Ljungqvist, Lars and Thomas J. Sargent. 1998. "The European Unemployment Dilemma" Journal of Political Economy 106: 514-550.

McCall, Brian P., "The Impact of Unemployment Insurance Benefit Levels on Recipiency," Journal of Business \& Economic Statistics, XII (1995), 189-198.

Meyer, Bruce D. (1989), "A Quasi-Experimental Approach to the Effects of Unemployment Insurance," April 1989, National Bureau of Economic Research Working Paper No. 3159.

Meyer, Bruce D. (1990), "Unemployment Insurance and Unemployment Spells," Econometrica, July 1990, 757-782.

Meyer, Bruce D. (2002), "Unemployment and Workers' Compensation Programmes: Rationale, Design, Labour Supply and Income Support," Fiscal Studies 23, March 2002, 1-49

Meyer, Bruce D., Viscusi, W. Kip and Durbin, David (1995), "Workers' Compensation and Injury Duration: Evidence from a Natural Experiment", American Economic Review, vol. 85, pp. 322-340.

Moffitt, Robert (1985): "Unemployment Insurance and the Distribution of Unemployment Spells," Journal of Econometrics, 28, 85-101.

Moffitt, Robert (1992): "Evaluation Methods for Program Entry Effects," in Evaluating Welfare and Training Programs, Charles F. Manski and Irwin Garfinkel, eds. Cambridge: Harvard University Press. 
Mortensen, Dale T. (1977): "Unemployment Insurance and Job Search Decisions," Industrial and Labor Relations Review, 30, 505-517.

Røed, Knut, Zhang, Tao (2003): "Does Unemployment Compensation Affect Unemployment Duration?" Economic Journal 113, 190-206.

Røed, Knut and Zhang, Tao (2005): "Unemployment Duration and Economic Incentives - A Quasi Random-Assignment Approach,”European Economic Review, 49, 1799-1825.

Solon, Gary, "Unemployment Insurance, Filing Delay, and Unemployment Duration," Working Paper \#144, Industrial Relations Section, Princeton University, 1981.

Solon, Gary, "Work Incentive Effects of Taxing Unemployment Benefits," Econometrica, March $1985,53,295-306$.

Topel, Robert H., "On Layoffs and Unemployment Insurance," American Economic Review, September 1983, 73, 541-559.

Topel, Robert H., "Experience Rating of Unemployment Insurance and the Incidence of Unemployment," Journal of Law \& Economics, October 1984, 27, 61-90.

U. S. Department of Labor, Bureau of Labor Statistics, Current Wage Developments, February 1988 to January 1990.

U. S. Department of Labor, Bureau of Labor Statistics, Mass Layoffs in 1988, Bulletin 2344, November 1989.

U. S. Department of Labor, Bureau of Labor Statistics, Mass Layoffs in 1989, Bulletin 2375, November 1990.

Vroman, Wayne (1991): The Decline in Unemployment Insurance Claims Activity in the 1980s, Unemployment Insurance Occasional Paper 91-2, U.S. Department of Labor, Employment and Training Administration, Unemployment Insurance Service.

Welch, Finis, "What Have We Learned from Empirical Studies of Unemployment Insurance?," Industrial and Labor Relations Review, July 1977, 30, 451-461. 
Figure 1

New York State UI Benefit Schedule

Before and After April 17, 1989 Increase in Benefits

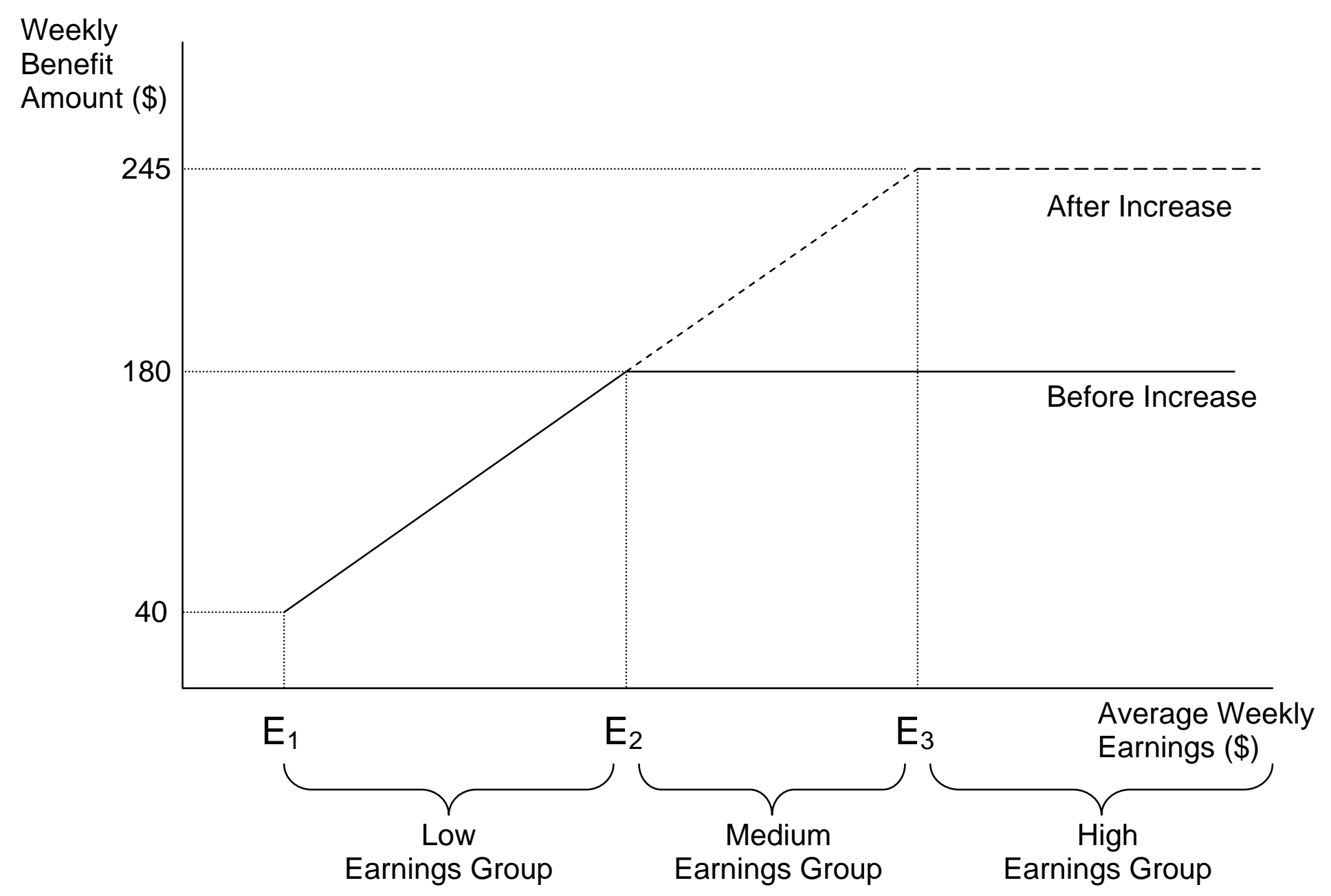


Figure 2

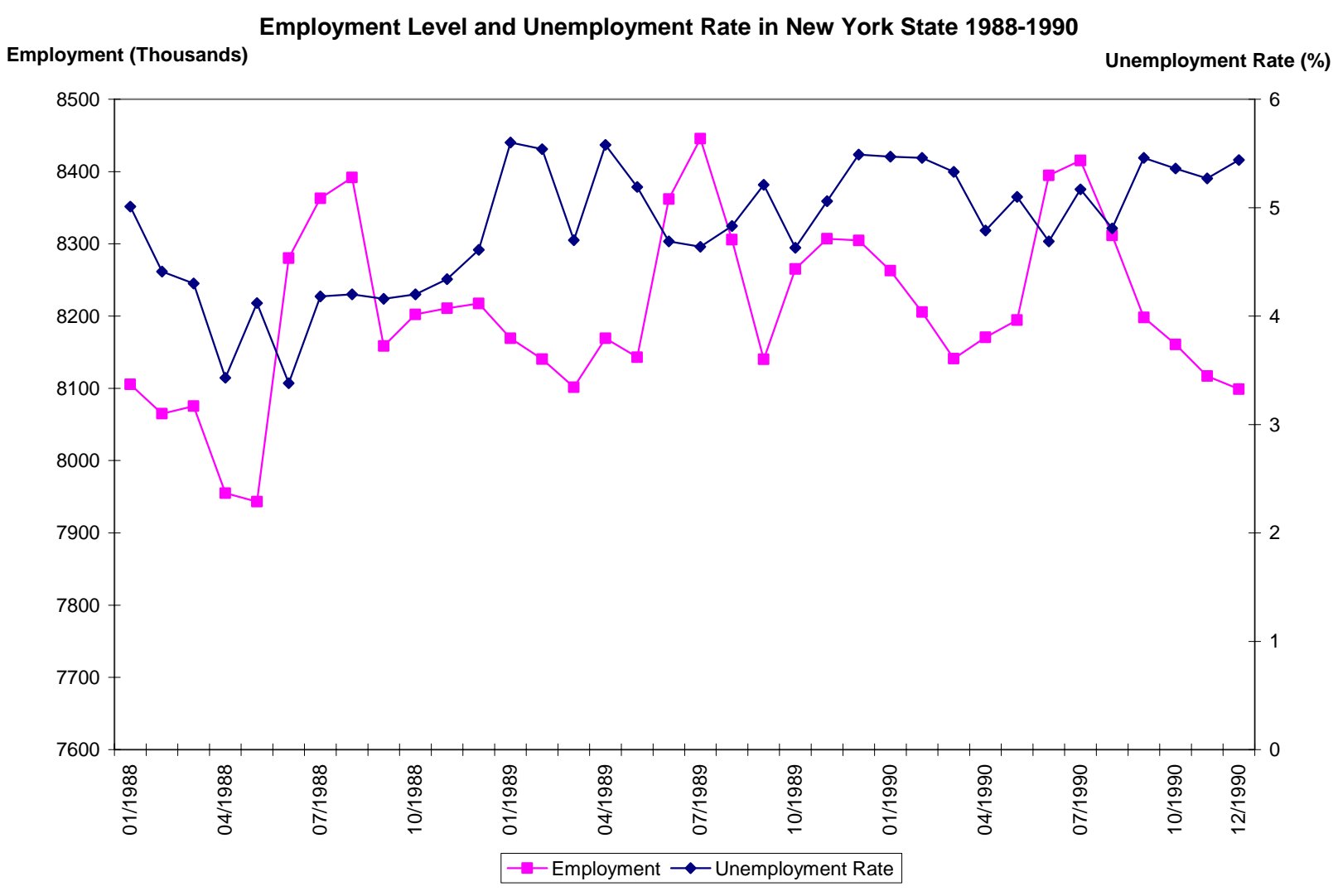

SOURCE: Employment and Earnings, various issues. 


\section{Figure 3}

\section{Empirical Hazard of 1988 First Quarter Claimants, High Earnings Group and Low Earnings Group}

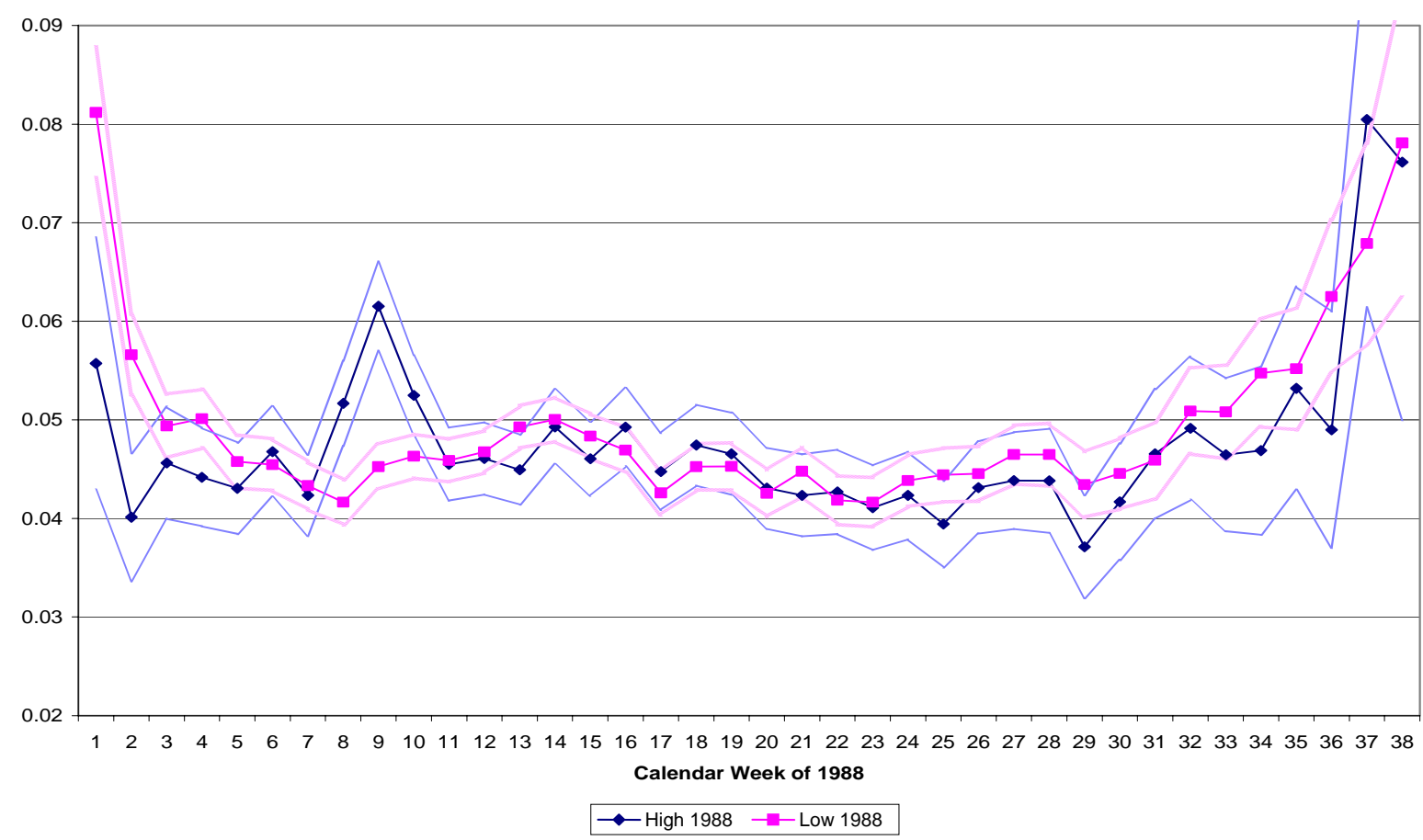

\section{Empirical Hazard of 1989 First Quarter Claimants, High Earnings Group and Low Earnings Group}

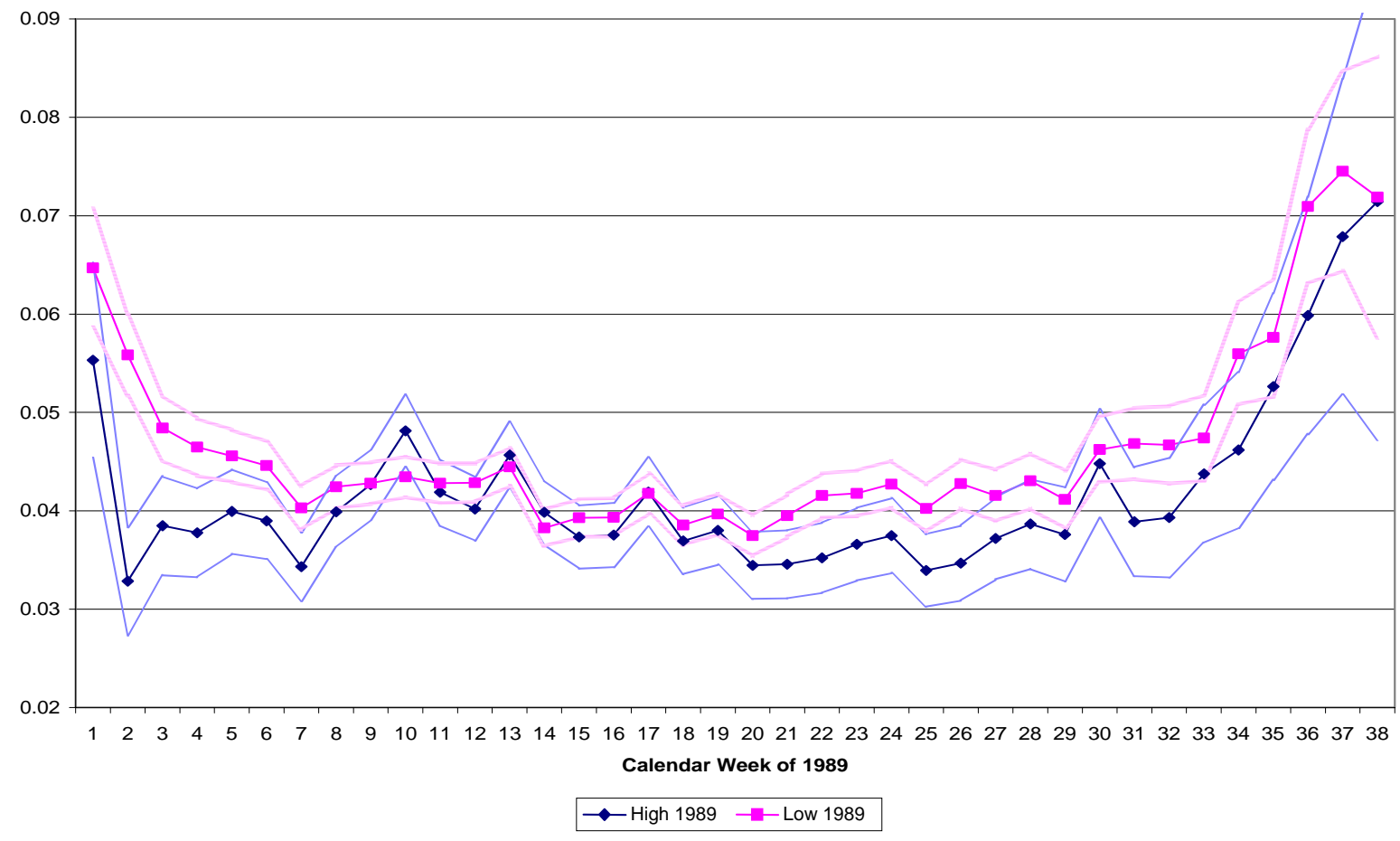

Note: These graphs show the Kaplan-Meier hazards for the High and Low Earnings Groups. Only first quarter data are included, and those who worked in the construction industry are deleted. 95\% confidence bands are also displayed. 
TABLE 1

Monthly Employment, Unemployment, and Labor Force New York, 1988-1990 (thousands)

\begin{tabular}{|c|c|c|c|c|}
\hline Month & Employment & Unemployment & Labor Force & $\begin{array}{c}\text { Unemployment } \\
\text { Rate }\end{array}$ \\
\hline \multicolumn{5}{|l|}{1988} \\
\hline January & 8105.4 & 427.5 & 8532.9 & 5.01 \\
\hline February & 8064.9 & 372.1 & 8437.0 & 4.41 \\
\hline March & 8075.5 & 362.6 & 8438.1 & 4.30 \\
\hline April & 7954.9 & 282.9 & 8237.8 & 3.43 \\
\hline May & 7943.2 & 341.0 & 8284.2 & 4.12 \\
\hline June & 8280.1 & 289.8 & 8569.9 & 3.38 \\
\hline July & 8362.8 & 365.1 & 8727.9 & 4.18 \\
\hline August & 8391.8 & 367.8 & 8759.6 & 4.20 \\
\hline September & 8158.6 & 354.0 & 8512.6 & 4.16 \\
\hline October & 8202.4 & 360.0 & 8562.4 & 4.20 \\
\hline November & 8210.8 & 372.3 & 8583.1 & 4.34 \\
\hline December & 8217.3 & 396.9 & 8614.2 & 4.61 \\
\hline \multicolumn{5}{|l|}{1989} \\
\hline January & 8169.3 & 484.7 & 8654.0 & 5.60 \\
\hline February & 8140.5 & 477.2 & 8617.7 & 5.54 \\
\hline March & 8101.6 & 399.5 & 8501.1 & 4.70 \\
\hline April & 8169.3 & 483.2 & 8652.5 & 5.58 \\
\hline May & 8143.2 & 445.4 & 8588.6 & 5.19 \\
\hline June & 8361.9 & 411.9 & 8773.8 & 4.69 \\
\hline July & 8445.3 & 411.2 & 8856.5 & 4.64 \\
\hline August & 8305.7 & 421.1 & 8726.8 & 4.83 \\
\hline September & 8140.1 & 447.4 & 8587.5 & 5.21 \\
\hline October & 8265.1 & 401.2 & 8666.3 & 4.63 \\
\hline November & 8307.0 & 442.4 & 8749.4 & 5.06 \\
\hline December & 8304.7 & 482.1 & 8786.8 & 5.49 \\
\hline \multicolumn{5}{|l|}{1990} \\
\hline January & 8262.9 & 478.2 & 8741.1 & 5.47 \\
\hline February & 8205.6 & 474.1 & 8679.7 & 5.46 \\
\hline March & 8141.0 & 458.5 & 8599.5 & 5.33 \\
\hline April & 8170.4 & 410.9 & 8581.3 & 4.79 \\
\hline May & 8194.5 & 440.8 & 8635.3 & 5.10 \\
\hline June & 8394.8 & 413.4 & 8808.2 & 4.69 \\
\hline July & 8415.4 & 458.9 & 8874.3 & 5.17 \\
\hline August & 8311.4 & 419.6 & 8731.0 & 4.81 \\
\hline September & 8198.1 & 473.4 & 8671.5 & 5.46 \\
\hline october & 8160.9 & 462.2 & 8623.1 & 5.36 \\
\hline November & 8116.8 & 451.7 & 8568.5 & 5.27 \\
\hline December & 8098.8 & 465.9 & 8564.2 & 5.44 \\
\hline
\end{tabular}

SOURCE: Employment and Earnings, various issues. 
TABLE 2

Quarterly Employment by Major Industry, its Ratio to the 1987 Average, and Measures of Variability New York State, 1987-1989 (thousands)

\begin{tabular}{|c|c|c|c|c|c|c|c|c|c|}
\hline & Construction & $\begin{array}{r}\text { Durable } \\
\text { Manufacturing } \\
\end{array}$ & $\begin{array}{r}\text { Nondurable } \\
\text { Manufacturing } \\
\end{array}$ & Transport & Trade & FIRE & Services & Government & Non-Agriculture \\
\hline \multirow[t]{2}{*}{ 1987:1 } & 286.4 & 672.7 & 546.3 & 284.3 & 1650.7 & 774.2 & 2158.0 & 1398.0 & 7770.6 \\
\hline & 0.8709 & 1.0117 & 0.987 & 0.9812 & 0.975 & 0.9757 & 0.9752 & 0.9971 & 0.9788 \\
\hline \multirow[t]{2}{*}{$1987: 2$} & 329.2 & 662.9 & 553.7 & 289.8 & 1688.4 & 789.6 & 2214.3 & 1416.5 & 7944.5 \\
\hline & 1.0011 & 0.997 & 1.0003 & 1.0004 & 0.9973 & 0.9951 & 1.0007 & 1.0102 & 1.0008 \\
\hline \multirow[t]{2}{*}{ 1987:3 } & 354.4 & 659.9 & 556.4 & 288.9 & 1698.3 & 807.4 & 2221.6 & 1367.2 & 7954.2 \\
\hline & 1.0778 & 0.9925 & 1.0052 & 0.9971 & 1.0031 & 1.0175 & 1.0039 & 0.9751 & 1.002 \\
\hline \multirow[t]{2}{*}{$1987: 4$} & 345.4 & 664.0 & 557.7 & 295.9 & 1734.5 & 802.8 & 2257.6 & 1426.8 & 8084.7 \\
\hline & 1.0502 & 0.9987 & 1.0075 & 1.0213 & 1.0245 & 1.0117 & 1.0202 & 1.0176 & 1.0184 \\
\hline \multirow[t]{2}{*}{$1988: 1$} & 300.7 & 657.6 & 542.4 & 290.2 & 1679.4 & 796.8 & 2214.3 & 1433.1 & 7914.5 \\
\hline & 0.9145 & 0.989 & 0.9799 & 1.0016 & 0.992 & 1.0041 & 1.0006 & 1.0221 & 0.997 \\
\hline \multirow[t]{2}{*}{ 1988:2 } & 342 & 665.9 & 547.1 & 296.0 & 1711.3 & 797.9 & 2266.4 & 1450.5 & 8077.1 \\
\hline & 1.04 & 1.0015 & 0.9883 & 1.0218 & 1.0108 & 1.0056 & 1.0242 & 1.0345 & 1.0175 \\
\hline \multirow[t]{2}{*}{ 1988:3 } & 360.8 & 666.7 & 549.2 & 297.8 & 1720 & 799.3 & 2281.8 & 1396.9 & 8072.4 \\
\hline & 1.0972 & 1.0027 & 0.9921 & 1.0278 & 1.016 & 1.0073 & 1.0311 & 0.9963 & 1.0169 \\
\hline \multirow[t]{2}{*}{ 1988:4 } & 347.7 & 669.3 & 551.8 & 304.1 & 1758.2 & 795.2 & 2312.5 & 1445.5 & 8184.4 \\
\hline & 1.0574 & 1.0066 & 0.9969 & 1.0498 & 1.0385 & 1.0021 & 1.045 & 1.0310 & 1.031 \\
\hline \multirow[t]{2}{*}{ 1989:1 } & 304.2 & 656 & 537.6 & 299.7 & 1699.8 & 788.30 & 2287.1 & 1450.1 & 8022.8 \\
\hline & 0.9251 & 0.9867 & 0.9711 & 1.0344 & 1.0041 & 0.9934 & 1.0335 & 1.0342 & 1.0106 \\
\hline \multirow{2}{*}{ 1989:2 } & 339.1 & 652.5 & 543.7 & 308.1 & 1726.1 & 794.3 & 2345.7 & 1465.5 & 8174.9 \\
\hline & 1.0313 & 0.9813 & 0.9821 & 1.0634 & 1.0195 & 1.0009 & 1.0600 & 1.0452 & 1.0298 \\
\hline \multirow[t]{2}{*}{ 1989:3 } & 360 & 646.7 & 543.8 & 308.0 & 1725.5 & 794.0 & 2352.8 & 1404.6 & 8135.2 \\
\hline & 1.0946 & 0.9726 & 0.9823 & 1.063 & 1.0192 & 1.0006 & 1.0632 & 1.0018 & 1.0248 \\
\hline \multirow[t]{2}{*}{ 1989:4 } & 342.9 & 639.1 & 536.9 & 318.5 & 1744.2 & 786.4 & 2375.6 & 1470 & 8213.5 \\
\hline & 1.0428 & 0.9612 & 0.9699 & 1.0994 & 1.0302 & 0.991 & 1.0735 & 1.0484 & 1.0346 \\
\hline \multicolumn{10}{|c|}{$\underline{\text { Coefficient of Variation }}$} \\
\hline Levels & 7.315 & 1.474 & 1.242 & 3.3 & 1.747 & 1.082 & 2.876 & 2.189 & 1.622 \\
\hline Logs & 1.302 & 0.228 & 0.197 & 0.575 & 0.236 & 0.163 & 0.373 & 0.303 & 0.181 \\
\hline \multicolumn{10}{|c|}{ Variance of Detrended Log Employment Residuals $\left({ }^{*} 10^{3}\right)$} \\
\hline & 4.856 & 0.099 & 0.089 & 0.113 & 0.162 & 0.118 & 0.071 & 0.314 & 0.082 \\
\hline
\end{tabular}


TABLE 3

Incidence and Duration of UI Claims by Quarter

Year Before and Year of Benefit Increase

\begin{tabular}{|c|c|c|c|c|}
\hline & $\begin{array}{l}\text { First } \\
\text { Quarter }\end{array}$ & $\begin{array}{l}\text { Second } \\
\text { Quarter }\end{array}$ & $\begin{array}{l}\text { Third } \\
\text { Quarter }\end{array}$ & $\begin{array}{l}\text { Fourth } \\
\text { Quarter }\end{array}$ \\
\hline \multicolumn{5}{|c|}{ Number of Claims (Incidence) } \\
\hline \multicolumn{5}{|c|}{ High Earnings Group } \\
\hline 1988 & 25384 & 18961 & 21926 & 19604 \\
\hline 1989 & 23722 & 22718 & 30842 & 27456 \\
\hline $1989 / 1988$ & $\begin{array}{c}0.9345 \\
(\odot .0084)\end{array}$ & $\begin{array}{c}1.1981 \\
(0.0118)\end{array}$ & $\begin{array}{c}1.4066 \\
(0.0124)\end{array}$ & $\begin{array}{c}1.4005 \\
(0.0131)\end{array}$ \\
\hline \multicolumn{5}{|c|}{ Medium Earnings Group } \\
\hline 1988 & 16604 & 11980 & 12767 & 14833 \\
\hline 1989 & 15802 & 13746 & 15862 & 17430 \\
\hline 1989/1988 & $\begin{array}{c}\odot .9517 \\
(\odot .0106)\end{array}$ & $\begin{array}{c}1.1474 \\
(0.0143)\end{array}$ & $\begin{array}{c}1.2424 \\
(0.0148)\end{array}$ & $\begin{array}{c}1.1751 \\
(0.0131)\end{array}$ \\
\hline \multicolumn{5}{|c|}{ Low Earnings Group } \\
\hline 1988 & 63450 & 47374 & 52193 & 62727 \\
\hline 1989 & 64066 & 57089 & 58981 & 74468 \\
\hline $1989 / 1988$ & $\begin{array}{c}1.0097 \\
(\odot .0057)\end{array}$ & $\begin{array}{c}1.2051 \\
(0.0075)\end{array}$ & $\begin{array}{c}1.1301 \\
(0.0068)\end{array}$ & $\begin{array}{c}1.1872 \\
(0.0064)\end{array}$ \\
\hline High - Low & $\begin{array}{l}-0.0752 \\
(0.0102)\end{array}$ & $\begin{array}{l}-\odot .0 \odot 69 \\
(\odot .0140)\end{array}$ & $\begin{array}{c}\odot .2766 \\
(\odot .0142)\end{array}$ & $\begin{array}{c}0.2134 \\
(0.0146)\end{array}$ \\
\hline Medium - Low & $\begin{array}{l}-0.0580 \\
(0.0120)\end{array}$ & $\begin{array}{l}-0.0577 \\
(0.0162)\end{array}$ & $\begin{array}{c}0.1124 \\
(0.0163)\end{array}$ & $\begin{array}{l}-0.0121 \\
(0.0146)\end{array}$ \\
\hline \multicolumn{5}{|c|}{ Average Duration of Claims (Weeks) } \\
\hline \multicolumn{5}{|c|}{ High Earnings Group } \\
\hline 1988 & 14.8305 & 16.3682 & 13.8926 & 16.1360 \\
\hline 1989 & 16.1064 & 17.0709 & 13.6652 & 16.3244 \\
\hline $1989-1988$ & $\begin{array}{c}1.2759 \\
(\odot .0852)\end{array}$ & $\begin{array}{c}0.7027 \\
(0.0932)\end{array}$ & $\begin{array}{l}-0.2275 \\
(0.0884)\end{array}$ & $\begin{array}{c}\odot .1884 \\
(\odot .0891)\end{array}$ \\
\hline \multicolumn{5}{|c|}{ Medium Earnings Group } \\
\hline 1988 & 15.5545 & 16.7124 & 15.9172 & 16.3703 \\
\hline 1989 & 16.2726 & 17.2976 & 16.3646 & 17.2426 \\
\hline $1989-1988$ & $\begin{array}{c}0.7181 \\
(\odot .1058)\end{array}$ & $\begin{array}{c}0.5852 \\
(0.1187)\end{array}$ & $\begin{array}{c}0.4473 \\
(0.1163)\end{array}$ & $\begin{array}{c}0.8723 \\
(0.1060)\end{array}$ \\
\hline \multicolumn{5}{|c|}{ Low Earnings Group } \\
\hline 1988 & 14.8878 & 15.6045 & 14.2683 & 16.0267 \\
\hline 1989 & 15.5005 & 15.7965 & 15.0752 & 16.4805 \\
\hline $1989-1988$ & $\begin{array}{c}0.6128 \\
(0.0535)\end{array}$ & $\begin{array}{c}0.1920 \\
(0.0586)\end{array}$ & $\begin{array}{c}\odot .8069 \\
(0.0571)\end{array}$ & $\begin{array}{c}0.4538 \\
(0.0500)\end{array}$ \\
\hline High - Low & $\begin{array}{c}0.6631 \\
(0.1007)\end{array}$ & $\begin{array}{c}0.5107 \\
(0.1100)\end{array}$ & $\begin{array}{l}-1.0344 \\
(0.1052)\end{array}$ & $\begin{array}{l}-0.2654 \\
(0.1022)\end{array}$ \\
\hline Medium - Low & $\begin{array}{c}0.1053 \\
(\odot .1186)\end{array}$ & $\begin{array}{c}0.3932 \\
(0.1324)\end{array}$ & $\begin{array}{l}-0.3596 \\
(0.1295)\end{array}$ & $\begin{array}{c}0.4185 \\
(0.1172)\end{array}$ \\
\hline
\end{tabular}

Note: Standard errors are in parentheses. The standard errors for ratios of number of claims are calculated using the delta method applied to (sample size after)/(sample size after + sample size before) treated as a binomial. The sample excludes those who worked in the construction industry prior to employment and includes some claimants who did not receive unemployment benefits. 
TABLE 4

Actual and Predicted Duration in 1988 and 1989 using Linear Regression Equations Estimated on 1988 Data

\begin{tabular}{|c|c|c|c|}
\hline & High & Medium & Low \\
\hline \multicolumn{4}{|l|}{$1^{\text {st }}$ Quarter } \\
\hline 1988 Actual and Predicted & 14.7666 & 15.5758 & 14.8893 \\
\hline $\mathrm{R}^{2}$ & $\odot .0917$ & $\odot .0963$ & 0.0914 \\
\hline 1989 Predicted & 14.8040 & 15.6821 & 14.9228 \\
\hline 1989 Actual & 15.9789 & 16.2136 & 15.4690 \\
\hline 1989 Predicted -1988 & $\begin{array}{c}0.0374 \\
(0.0124)\end{array}$ & $\begin{array}{c}0.1063 \\
(0.0147)\end{array}$ & $\begin{array}{c}0.0335 \\
(0.0064)\end{array}$ \\
\hline \multicolumn{4}{|l|}{$2^{\text {nd }}$ Quarter } \\
\hline 1988 Actual and Predicted & 16.2423 & 16.9157 & 15.6706 \\
\hline $\mathrm{R}^{2}$ & $\odot .0692$ & $\odot .0945$ & $\odot .0803$ \\
\hline 1989 Predicted & 16.0035 & 16.7744 & 15.5746 \\
\hline 1989 Actual & 16.8907 & 17.2887 & 15.7672 \\
\hline 1989 Predicted-1988 & $\begin{array}{l}-0.2388 \\
(0.0204)\end{array}$ & $\begin{array}{l}-0.1413 \\
(0.0159)\end{array}$ & $\begin{array}{l}-0.0960 \\
(0.0073)\end{array}$ \\
\hline \multicolumn{4}{|l|}{$3^{\text {rd }}$ Quarter } \\
\hline 1988 Actual and Predicted & 13.4507 & 15.8832 & 14.1761 \\
\hline $\mathrm{R}^{2}$ & $\odot .209 \odot$ & $\odot .0972$ & 0.1014 \\
\hline 1989 Predicted & 12.6883 & 15.6499 & 14.2015 \\
\hline 1989 Actual & 13.1597 & 16.3672 & 14.9582 \\
\hline 1989 Predicted -1988 & $\begin{array}{l}-0.7624 \\
(0.0167)\end{array}$ & $\begin{array}{l}-0.2333 \\
(0.0176)\end{array}$ & $\begin{array}{c}0.0254 \\
(0.0069)\end{array}$ \\
\hline \multicolumn{4}{|l|}{$4^{\text {th }}$ Quarter } \\
\hline 1988 Actual and Predicted & 15.9280 & 16.2567 & 15.9576 \\
\hline $\mathrm{R}^{2}$ & $\odot .0862$ & 0.1467 & ๑. 0982 \\
\hline 1989 Predicted & 15.5693 & 16.2958 & 15.7264 \\
\hline 1989 Actual & 15.9047 & 17.1116 & 16.4017 \\
\hline 1989 Predicted-1988 & $\begin{array}{l}-0.3587 \\
(0.0193)\end{array}$ & $\begin{array}{c}0.0391 \\
(0.0165)\end{array}$ & $\begin{array}{l}-0.2312 \\
(0.0056)\end{array}$ \\
\hline
\end{tabular}

Notes: (1) Separate regressions are estimated for each quarter and earnings group. (2) Each regression has duration in days as the dependent variable. All equations include a constant, base year earnings, weeks worked in the base year, age, gender, race and education indicator variables, industry and region indicator variables. (3) Those in construction, with missing demographics, no previous earnings, with weeks worked less than 20, real weekly earnings less than $\$ 80$ (\$84.24 in 1989), out of state observations and those with pension reductions are deleted. 
TABLE 5

First Quarter Regression Equations for Natural Logarithm of Duration

\begin{tabular}{|c|c|c|c|c|c|c|}
\hline \multirow{2}{*}{ Explanatory Variable } & \multicolumn{6}{|c|}{ Specification } \\
\hline & (1) & (2) & (3) & (4) & $(5)$ & (6) \\
\hline $\begin{array}{l}\text { After Increase* } \\
\text { High Earnings Group }\end{array}$ & $\begin{array}{c}\odot .0729 \\
(\odot .0152)\end{array}$ & $\begin{array}{l}\odot .0869 \\
(\odot .0153)\end{array}$ & & & & $\begin{array}{c}\odot .0478 \\
(\odot .0265)\end{array}$ \\
\hline $\begin{array}{l}\text { After Increase* } \\
\text { Medium Earnings Group }\end{array}$ & $\begin{array}{l}-0.0025 \\
(0.0173)\end{array}$ & $\begin{array}{c}\odot .0081 \\
(0.0174)\end{array}$ & & & & $\begin{array}{l}-\odot . \odot \odot 81 \\
(\odot .0191)\end{array}$ \\
\hline $\begin{array}{l}\text { (Ln(WBA Under New Law) } \\
\text { - Ln(WBA Under Old Law)) } \\
\text { *After Benefit Increase }\end{array}$ & & & $\begin{array}{c}\odot .2752 \\
(\odot .0896)\end{array}$ & $\begin{array}{c}\odot .4172 \\
(\odot .0959)\end{array}$ & $\begin{array}{l}\odot .3591 \\
(\odot .0976)\end{array}$ & $\begin{array}{c}\odot .2371 \\
(0.1789)\end{array}$ \\
\hline Ln(WBA Under old Law) & & & $\begin{array}{l}\odot .2610 \\
(\odot .0247)\end{array}$ & $\begin{array}{l}0.260 \odot \\
(0.0247)\end{array}$ & $\begin{array}{l}0.2615 \\
(0.0247)\end{array}$ & $\begin{array}{c}\odot .2617 \\
(\odot .0247)\end{array}$ \\
\hline Ln(Weekly Earnings) & $\begin{array}{l}\odot .1977 \\
(\odot .0107)\end{array}$ & $\begin{array}{l}\odot .1946 \\
(\odot .0107)\end{array}$ & $\begin{array}{l}-\odot . \odot \odot 43 \\
(\odot .0219)\end{array}$ & $\begin{array}{l}-0.0066 \\
(0.0219)\end{array}$ & $\begin{array}{l}-0.0076 \\
(0.0219)\end{array}$ & $\begin{array}{l}-\odot .0082 \\
(\odot .0220)\end{array}$ \\
\hline Ln(Weeks Worked) & $\begin{array}{l}-0.5534 \\
(0.0109)\end{array}$ & $\begin{array}{l}-0.5541 \\
(0.0109)\end{array}$ & $\begin{array}{l}-0.5640 \\
(0.0109)\end{array}$ & $\begin{array}{l}-0.5641 \\
(0.0109)\end{array}$ & $\begin{array}{l}-0.5646 \\
(0.0109)\end{array}$ & $\begin{array}{l}-0.5649 \\
(0.0109)\end{array}$ \\
\hline After Increase & $\begin{array}{l}-0.0032 \\
(\odot .0076)\end{array}$ & & $\begin{array}{l}-0.0032 \\
(0.0067)\end{array}$ & & & \\
\hline High Earnings Group & $\begin{array}{l}-0.2222 \\
(0.0158)\end{array}$ & & $\begin{array}{l}-0.1091 \\
(0.0169)\end{array}$ & $\begin{array}{l}-0.1219 \\
(0.0170)\end{array}$ & $\begin{array}{l}-0.1175 \\
(0.0170)\end{array}$ & \\
\hline Medium Earnings Group & $\begin{array}{l}-0.0383 \\
(0.0140)\end{array}$ & & $\begin{array}{l}-0.0499 \\
(0.0109)\end{array}$ & $\begin{array}{l}-0.0560 \\
(0.0109)\end{array}$ & $\begin{array}{l}-0.0541 \\
(0.0109)\end{array}$ & \\
\hline $\begin{array}{l}\text { Week Spell Began* } \\
\text { Before and After Increase }\end{array}$ & & yes & & yes & yes & yes \\
\hline $\begin{array}{l}\text { Week Spell Began* } \\
\text { High and Medium Earnings }\end{array}$ & & yes & & & & yes \\
\hline $\begin{array}{l}\text { Age, Sex, Education, and } \\
\text { Race Indicator Variables }\end{array}$ & yes & yes & yes & yes & yes & yes \\
\hline Industry Indicators & yes & yes & yes & yes & yes & yes \\
\hline Region Indicators & yes & yes & yes & yes & yes & yes \\
\hline $\begin{array}{l}\text { Industry and Region* } \\
\text { After Interactions }\end{array}$ & & & & & yes & yes \\
\hline $\mathrm{R}^{2}$ & 0.0518 & 0.0549 & 0.0523 & $\odot .0551$ & $\odot .0559$ & $\odot .0555$ \\
\hline
\end{tabular}

Notes: (1) Standard errors are in parentheses. (2) The sample size is 173,927. (3) All equations include a constant, and all earnings and benefit amounts are in 1988 dollars. (3) Durations of zero are recoded to 0.5. (4) Only Q1 observations are included, those in construction, with missing demographics, no previous earnings, with weeks worked less than 20, real weekly earnings less than $\$ 80$ (\$84.24 in 1989), out of state observations and those with pension reductions are deleted. 
TABLE 6

First Quarter Tobit Regression Equations for Natural Logarithm of Duration

\begin{tabular}{|c|c|c|c|c|c|c|}
\hline \multirow{2}{*}{ Explanatory Variable } & \multicolumn{6}{|c|}{ Specification } \\
\hline & (1) & $(2)$ & (3) & $(4)$ & (5) & (6) \\
\hline $\begin{array}{l}\text { After Increase* } \\
\text { High Earnings Group }\end{array}$ & $\begin{array}{l}\odot .1236 \\
(\odot .0223)\end{array}$ & $\begin{array}{l}\odot .1479 \\
(\odot .0224)\end{array}$ & & & & $\begin{array}{c}\odot .0838 \\
(\odot .0390)\end{array}$ \\
\hline $\begin{array}{l}\text { After Increase* } \\
\text { Medium Earnings Group }\end{array}$ & $\begin{array}{l}\odot .0117 \\
(\odot . \odot 255)\end{array}$ & $\begin{array}{l}\odot .0295 \\
(\odot .0256)\end{array}$ & & & & $\begin{array}{c}0.0021 \\
(0.0281)\end{array}$ \\
\hline $\begin{array}{l}\text { (Ln(WBA Under New Law) } \\
\text { - Ln(WBA Under Old Law)) } \\
{ }^{*} \text { After Benefit Increase }\end{array}$ & & & $\begin{array}{c}0.6253 \\
(0.1328)\end{array}$ & $\begin{array}{l}0.7015 \\
(0.1420)\end{array}$ & $\begin{array}{l}0.6085 \\
(0.1445)\end{array}$ & $\begin{array}{l}\odot .3981 \\
(\odot .2650)\end{array}$ \\
\hline Ln(WBA Under old Law) & & & $\begin{array}{c}0.4007 \\
(0.0366)\end{array}$ & $\begin{array}{l}0.3950 \\
(\odot .0366)\end{array}$ & $\begin{array}{l}0.3964 \\
(\odot .0366)\end{array}$ & $\begin{array}{c}0.3961 \\
(0.0367)\end{array}$ \\
\hline Ln(Weekly Earnings) & $\begin{array}{l}\odot .2985 \\
(\odot .0158)\end{array}$ & $\begin{array}{l}0.2927 \\
(0.0158)\end{array}$ & $\begin{array}{l}-0.0135 \\
(0.0325)\end{array}$ & $\begin{array}{l}-0.0143 \\
(0.0325)\end{array}$ & $\begin{array}{l}-\odot .0152 \\
(\odot .0325)\end{array}$ & $\begin{array}{l}-\odot .0158 \\
(\odot .0326)\end{array}$ \\
\hline Ln(Weeks Worked) & $\begin{array}{l}-0.7626 \\
(\odot .0163)\end{array}$ & $\begin{array}{l}-0.7657 \\
(\odot .0162)\end{array}$ & $\begin{array}{l}-0.7798 \\
(\odot .0163)\end{array}$ & $\begin{array}{l}-\odot .7814 \\
(\odot .0163)\end{array}$ & $\begin{array}{l}-0.7822 \\
(0.0163)\end{array}$ & $\begin{array}{l}-0.7829 \\
(0.0163)\end{array}$ \\
\hline After Increase & $\begin{array}{l}-\odot .0249 \\
(\odot .0112)\end{array}$ & & $\begin{array}{c}0.0335 \\
(\odot .0098)\end{array}$ & & & \\
\hline High Earnings Group & $\begin{array}{l}-\odot .3447 \\
(\odot .0232)\end{array}$ & & $\begin{array}{l}-0.1764 \\
(0.0250)\end{array}$ & $\begin{array}{l}-\odot .1886 \\
(\odot .0251)\end{array}$ & $\begin{array}{l}-0.1826 \\
(\odot .0252)\end{array}$ & \\
\hline Medium Earnings Group & $\begin{array}{l}-\odot .0529 \\
(\odot . \odot 206)\end{array}$ & & $\begin{array}{l}-0.0657 \\
(0.0161)\end{array}$ & $\begin{array}{l}-0.0724 \\
(0.0161)\end{array}$ & $\begin{array}{l}-0.0699 \\
(0.0161)\end{array}$ & \\
\hline $\begin{array}{l}\text { Week Spell Began* } \\
\text { Before and After Increase }\end{array}$ & & yes & & yes & yes & yes \\
\hline $\begin{array}{l}\text { Week Spell Began* } \\
\text { High and Medium Earnings }\end{array}$ & & yes & & & & yes \\
\hline $\begin{array}{l}\text { Age, Sex, Education, and } \\
\text { Race Indicator Variables }\end{array}$ & yes & yes & yes & yes & yes & yes \\
\hline Industry Indicators & yes & yes & yes & yes & yes & yes \\
\hline Region Indicators & yes & yes & yes & yes & yes & yes \\
\hline $\begin{array}{l}\text { Industry and Region* } \\
\text { After Interactions }\end{array}$ & & & & & yes & yes \\
\hline
\end{tabular}

Notes: (1) Standard errors are in parentheses. (2) The sample size is 173,927. (3) All equations include a constant, and all earnings and benefit amounts are in 1988 dollars. (4) Only Q1 observations are included, those in construction, with missing demographics, no previous earnings, with weeks worked less than 20, real weekly earnings less than $\$ 80$ (\$84.24 in 1989), out of state observations and those with pension reductions are deleted. The number of left censored observations is 6,810, while the number of right censored observations is 53,778. 
TABLE 7

First Quarter Duration Model Estimates,

Using Time-Period Interactions to Identify the Effect of the Benefit Increase

\section{Specification}

Explanatory Variable

(1)

(2)

(3)

(4)

(5)

(6)

\begin{tabular}{|c|c|c|c|c|c|c|}
\hline $\begin{array}{l}\text { After } 16^{\text {th }} \text { week of } \\
1989^{*} \mathrm{High} \text { Earnings } \\
\text { Group }\end{array}$ & $\begin{array}{l}-0.0587 \\
(0.0205)\end{array}$ & $\begin{array}{l}-0.0584 \\
(\odot .0205)\end{array}$ & $\begin{array}{l}-0.0582 \\
(0.0205)\end{array}$ & $\begin{array}{l}-0.0578 \\
(0.0205)\end{array}$ & $\begin{array}{l}-0.0608 \\
(0.0205)\end{array}$ & $\begin{array}{l}-0.0701 \\
(\odot .0282)\end{array}$ \\
\hline $\begin{array}{l}\text { After } 16^{\text {th }} \text { week of } \\
1989^{*} \text { Med Earnings } \\
\text { Group }\end{array}$ & & & $\begin{array}{l}-0.0418 \\
(0.0237)\end{array}$ & $\begin{array}{l}-\odot .0419 \\
(\odot .0237)\end{array}$ & $\begin{array}{l}-\odot .0437 \\
(\odot .0237)\end{array}$ & $\begin{array}{c}0.0032 \\
(0.0324)\end{array}$ \\
\hline High Earnings Group & $\begin{array}{c}\odot .2297 \\
(\odot .0149)\end{array}$ & $\begin{array}{c}0.2380 \\
(0.0149)\end{array}$ & $\begin{array}{c}0.2252 \\
(0.0148)\end{array}$ & $\begin{array}{c}0.2333 \\
(0.0148)\end{array}$ & $\begin{array}{l}\odot .2266 \\
(\odot .0149)\end{array}$ & $\begin{array}{c}0.1680 \\
(0.0203)\end{array}$ \\
\hline $\begin{array}{l}\text { Medium Earnings } \\
\text { Group }\end{array}$ & & & $\begin{array}{c}0.0267 \\
(0.0133)\end{array}$ & $\begin{array}{c}0.0312 \\
(0.0133)\end{array}$ & $\begin{array}{c}0.0267 \\
(\odot .0134)\end{array}$ & $\begin{array}{l}-0.0097 \\
(0.0182)\end{array}$ \\
\hline After*High Earnings & $\begin{array}{l}-0.0691 \\
(0.0178)\end{array}$ & $\begin{array}{l}-0.0795 \\
(\odot .0179)\end{array}$ & $\begin{array}{l}-0.0684 \\
(0.0178)\end{array}$ & $\begin{array}{l}-0.0785 \\
(\odot .0178)\end{array}$ & $\begin{array}{l}-0.0636 \\
(0.0182)\end{array}$ & $\begin{array}{l}-0.0202 \\
(0.0232)\end{array}$ \\
\hline After*Med Earnings & & & $\begin{array}{c}0.0027 \\
(0.0207)\end{array}$ & $\begin{array}{l}-0.0036 \\
(0.0207)\end{array}$ & $\begin{array}{l}0.0056 \\
(0.0208)\end{array}$ & $\begin{array}{l}-0.0301 \\
(0.0265)\end{array}$ \\
\hline $\begin{array}{l}\text { Week Spell Began } \\
\text { Indicators }\end{array}$ & & Yes & & Yes & Yes & Yes \\
\hline $\begin{array}{l}\text { Industry and Region* } \\
\text { After Interactions }\end{array}$ & & & & & Yes & Yes \\
\hline $\begin{array}{l}\text { Medium Earnings } \\
\text { Group Included in } \\
\text { Sample }\end{array}$ & & & Yes & Yes & Yes & Yes \\
\hline $\begin{array}{l}\text { Only Spells } \\
\text { Beginning in } \\
\text { Weeks } 1-6\end{array}$ & & & & & & Yes \\
\hline
\end{tabular}

Notes: (1) Standard errors are in parentheses. (2) Controls for previous earnings, previous weeks worked, age, gender, education, race, industry and region are included. In addition, indicator variables for each calendar week are included.

(3) Only Q1 observations are included, those in construction, with missing demographics, no previous earnings, with weeks worked less than 20, real weekly earnings less than $\$ 80$ (\$84.24 in 1989), out of state observations and those with pension reductions are deleted. 
Table 8

First Quarter Duration Model Estimates, Using Benefit Level Variables to Capture the Effect of the Benefit Increase

\begin{tabular}{|c|c|c|c|c|c|c|c|}
\hline \multirow{2}{*}{ Explanatory Variable } & \multicolumn{7}{|c|}{ Specification } \\
\hline & (1) & (2) & (3) & $(4)$ & (5) & (6) & ( 7 ) \\
\hline $\begin{array}{l}\text { Ln(WBA in Current Week) } \\
-\operatorname{Ln}(\text { WBA Under Old Law) }\end{array}$ & $\begin{array}{l}-0.3308 \\
(0.0600)\end{array}$ & $\begin{array}{l}-0.3468 \\
(0.0599)\end{array}$ & $\begin{array}{l}-0.2965 \\
(\odot .0560)\end{array}$ & $\begin{array}{l}-\odot .2797 \\
(\odot .0563)\end{array}$ & $\begin{array}{l}-0.1840 \\
(0.0613)\end{array}$ & $\begin{array}{l}-\odot .1794 \\
(\odot .0848)\end{array}$ & $\begin{array}{l}-0.3037 \\
(0.0567)\end{array}$ \\
\hline Ln(WBA Under old Law) & $\begin{array}{l}-0.1825 \\
(0.0243)\end{array}$ & $\begin{array}{l}-\odot .1820 \\
(\odot .0243)\end{array}$ & $\begin{array}{l}-0.2028 \\
(\odot .0237)\end{array}$ & $\begin{array}{l}-0.2066 \\
(\odot .0238)\end{array}$ & $\begin{array}{l}-0.2062 \\
(0.0238)\end{array}$ & $\begin{array}{l}-0.1010 \\
(0.0323)\end{array}$ & $\begin{array}{l}-1.9432 \\
(0.7807)\end{array}$ \\
\hline High Earnings Group & $\begin{array}{c}\odot .1314 \\
(0.0160)\end{array}$ & $\begin{array}{l}\odot .1355 \\
(\odot .0160)\end{array}$ & $\begin{array}{c}\odot .1187 \\
(\odot .0157)\end{array}$ & $\begin{array}{c}\odot .1165 \\
(\odot .0157)\end{array}$ & $\begin{array}{c}\odot .1453 \\
(\odot .0172)\end{array}$ & $\begin{array}{c}\odot .1193 \\
(\odot .0232)\end{array}$ & $\begin{array}{l}-\odot .0082 \\
(0.0431)\end{array}$ \\
\hline Medium Earnings Group & & & $\begin{array}{c}0.0243 \\
(0.0104)\end{array}$ & $\begin{array}{c}0.0235 \\
(\odot .0104)\end{array}$ & $\begin{array}{c}0.0241 \\
(0.0134)\end{array}$ & $\begin{array}{l}-0.0168 \\
(0.0181)\end{array}$ & $\begin{array}{c}0.0444 \\
(\odot .0363)\end{array}$ \\
\hline After*High Earnings & & & & & $\begin{array}{l}-0.0664 \\
(0.0163)\end{array}$ & $\begin{array}{l}-\odot .0229 \\
(\odot .0212)\end{array}$ & \\
\hline After*Medium Earnings & & & & & $\begin{array}{l}-\odot .0040 \\
(0.0170)\end{array}$ & $\begin{array}{l}\odot . \odot 447 \\
(\odot .0229)\end{array}$ & \\
\hline $\begin{array}{l}\text { Week Spell Began } \\
\text { Indicators }\end{array}$ & & Yes & & & & & \\
\hline $\begin{array}{l}\text { Industry and Region* } \\
\text { After Interactions }\end{array}$ & & & & Yes & Yes & Yes & Yes \\
\hline Ln(Earnings)Spline & & & & & & & Yes \\
\hline $\begin{array}{l}\text { Medium Earnings Group } \\
\text { Included in Sample }\end{array}$ & & & Yes & Yes & Yes & Yes & Yes \\
\hline $\begin{array}{l}\text { Only Spells Beginning } \\
\text { in Weeks } 1-6\end{array}$ & & & & & & Yes & \\
\hline Compensated Duration & & & & & & & \\
\hline Elasticity & 0.1629 & 0.1686 & 0.1443 & 0.1363 & $\odot .0897$ & $\odot .0900$ & 0.1478 \\
\hline $\begin{array}{l}\text { Total Duration } \\
\text { Elasticity }\end{array}$ & $\odot .2205$ & $\odot .2283$ & $\odot .1958$ & 0.1849 & 0.1216 & 0.1212 & 0.2005 \\
\hline
\end{tabular}

Notes: (1) Standard errors are in parentheses. (2) Controls for previous earnings, previous weeks worked, age, gender, education, race, industry and region are included. In addition, indicator variables for each calendar week, and the current spell length are included. (3) Only Q1 observations are included, those in construction, with missing demographics, no previous earnings, with weeks worked less than 20, real weekly earnings less than \$80 (\$84.24 in 1989), out of state observations and those with pension reductions are deleted. (4) The compensated and total duration elasticities are computed based on a simulated $10 \%$ benefit increase. 
Table 9

First Quarter Duration Model Estimates, Table 8 Specifications, Compensated and Total Duration Elasticities for Subsamples

\begin{tabular}{|c|c|c|c|c|c|c|}
\hline & \multicolumn{5}{|c|}{ Specification } & \multirow[b]{2}{*}{ (6) } \\
\hline & $(1)$ & $(2)$ & (3) & $(4)$ & (5) & \\
\hline \multicolumn{7}{|l|}{ Male } \\
\hline $\begin{array}{l}\text { Ln(WBA in Current Week) } \\
\text { - Ln(WBA Under Old Law) }\end{array}$ & $\begin{array}{l}-\odot .3177 \\
(0.074 \odot)\end{array}$ & $\begin{array}{l}-0.3212 \\
(0.0740)\end{array}$ & $\begin{array}{l}-\odot .2510 \\
(\odot . \odot 70 \odot)\end{array}$ & $\begin{array}{l}-0.2279 \\
(0.0703)\end{array}$ & $\begin{array}{l}-\odot .1080 \\
(\odot .0769)\end{array}$ & $\begin{array}{l}-0.3320 \\
(0.1048)\end{array}$ \\
\hline Compensated Elasticity & $\odot .1594$ & 0.1594 & 0.1243 & 0.1129 & 0.0535 & 0.1665 \\
\hline Total Duration Elasticity & 0.2128 & 0.2128 & $\odot .1665$ & 0.1511 & $\odot .0715$ & 0.2229 \\
\hline \multicolumn{7}{|l|}{ Female } \\
\hline $\begin{array}{l}\text { Ln(WBA in Current Week) } \\
-\operatorname{Ln}(\text { WBA Under Old Law) }\end{array}$ & $\begin{array}{l}-0.5520 \\
(0.1168)\end{array}$ & $\begin{array}{l}-0.5843 \\
(0.1167)\end{array}$ & $\begin{array}{l}-0.6528 \\
(0.1044)\end{array}$ & $\begin{array}{l}-0.6437 \\
(0.1052)\end{array}$ & $\begin{array}{l}-0.7343 \\
(0.1128)\end{array}$ & $\begin{array}{l}-0.6649 \\
(0.1609)\end{array}$ \\
\hline Compensated Elasticity & 0.2631 & 0.2745 & 0.3068 & 0.3032 & 0.3453 & 0.3271 \\
\hline Total Duration Elasticity & $\odot .3600$ & 0.3757 & $\odot .4216$ & 0.4167 & $\odot .4748$ & 0.4426 \\
\hline \multicolumn{7}{|l|}{ Age Less than 40} \\
\hline $\begin{array}{l}\text { Ln(WBA in Current Week) } \\
\text { - Ln(WBA Under Old Law) }\end{array}$ & $\begin{array}{l}-\odot .0583 \\
(0.0823)\end{array}$ & $\begin{array}{l}-\odot .0691 \\
(\odot .0823)\end{array}$ & $\begin{array}{l}-\odot .0605 \\
(\odot .0759)\end{array}$ & $\begin{array}{l}-\odot .0371 \\
(\odot . \odot 764)\end{array}$ & $\begin{array}{l}\odot .0197 \\
(\odot .0822)\end{array}$ & $\begin{array}{c}\odot .0174 \\
(0.1144)\end{array}$ \\
\hline Compensated Elasticity & $\odot .0309$ & $\odot .0362$ & $\odot .0316$ & $\odot .0194$ & -0.0103 & $-\odot .0 \odot 93$ \\
\hline Total Duration Elasticity & 0.0410 & $\odot .0481$ & $\odot .0421$ & $\odot .0259$ & -0.0137 & $-\odot .0124$ \\
\hline \multicolumn{7}{|l|}{ Age 40 and above } \\
\hline $\begin{array}{l}\text { Ln(WBA in Current Week) } \\
\text { - Ln(WBA Under Old Law) }\end{array}$ & $\begin{array}{l}-\odot .7067 \\
(\odot .0884)\end{array}$ & $\begin{array}{l}-0.7414 \\
(0.0884)\end{array}$ & $\begin{array}{l}-\odot .6456 \\
(\odot .0835)\end{array}$ & $\begin{array}{l}-\odot .6397 \\
(\odot .0841)\end{array}$ & $\begin{array}{l}-\odot .5550 \\
(\odot .0930)\end{array}$ & $\begin{array}{l}-0.4759 \\
(\odot .1275)\end{array}$ \\
\hline Compensated Elasticity & 0.3166 & $\odot .3269$ & $\odot .2864$ & 0.2835 & $\odot .2463$ & 0.2184 \\
\hline Total Duration Elasticity & $\odot .4457$ & 0.4600 & $\odot .4040$ & 0.3989 & $\odot .3461$ & 0.3045 \\
\hline
\end{tabular}

Notes: (1) Standard errors for the Ln(WBA in Current Week)-Ln(WBA Under Old Law) coefficients are in parentheses. (2) The specifications for these models are based on those in Table 8. See Table 8 for details on specification. (3) The compensated and total duration elasticities are computed based on a simulated $10 \%$ benefit increase. 
APPENDIX TABLE 1

Average Monthly Employment by Substate Region

New York State, 1988 and 1989 (thousands)

\begin{tabular}{lccc}
\hline \hline & & & \\
Sub-state Region & April to october Average Monthly Employment \\
& 1988 & 1989 & $1989 / 1988$ \\
\hline New York PMSA & 3913.0 & 3964.5 & 1.0132 \\
Nassau-Suffolk PMSA & 1379.9 & 1380.4 & 1.0004 \\
Albany-Schenectady-Troy MSA & 410.9 & 421.4 & 1.0254 \\
Poughkeepsie MSA & 125.8 & 126.6 & 1.0062 \\
Orange County PMSA & 129.5 & 132.9 & 1.0264 \\
Binghamton MSA & 122.7 & 120.8 & 0.9849 \\
Buffalo PMSA & 430.2 & 440.3 & 1.0235 \\
Rochester MSA & 485.5 & 496.3 & 1.0223 \\
Syracuse MSA & 302.4 & 310.1 & 1.0253 \\
Utica-Rome MSA & 130.2 & 132.9 & 1.0208 \\
\hline
\end{tabular}

SOURCE: New York State Department of Labor (1991), Resident Employment Status of the Civilian Labor Force, 1974-1991. 
APPENDIX TABLE 2

Means and Standard Deviations of Various Characteristics, First Quarter Observations in the Year Before and the Year of the Benefit Increase

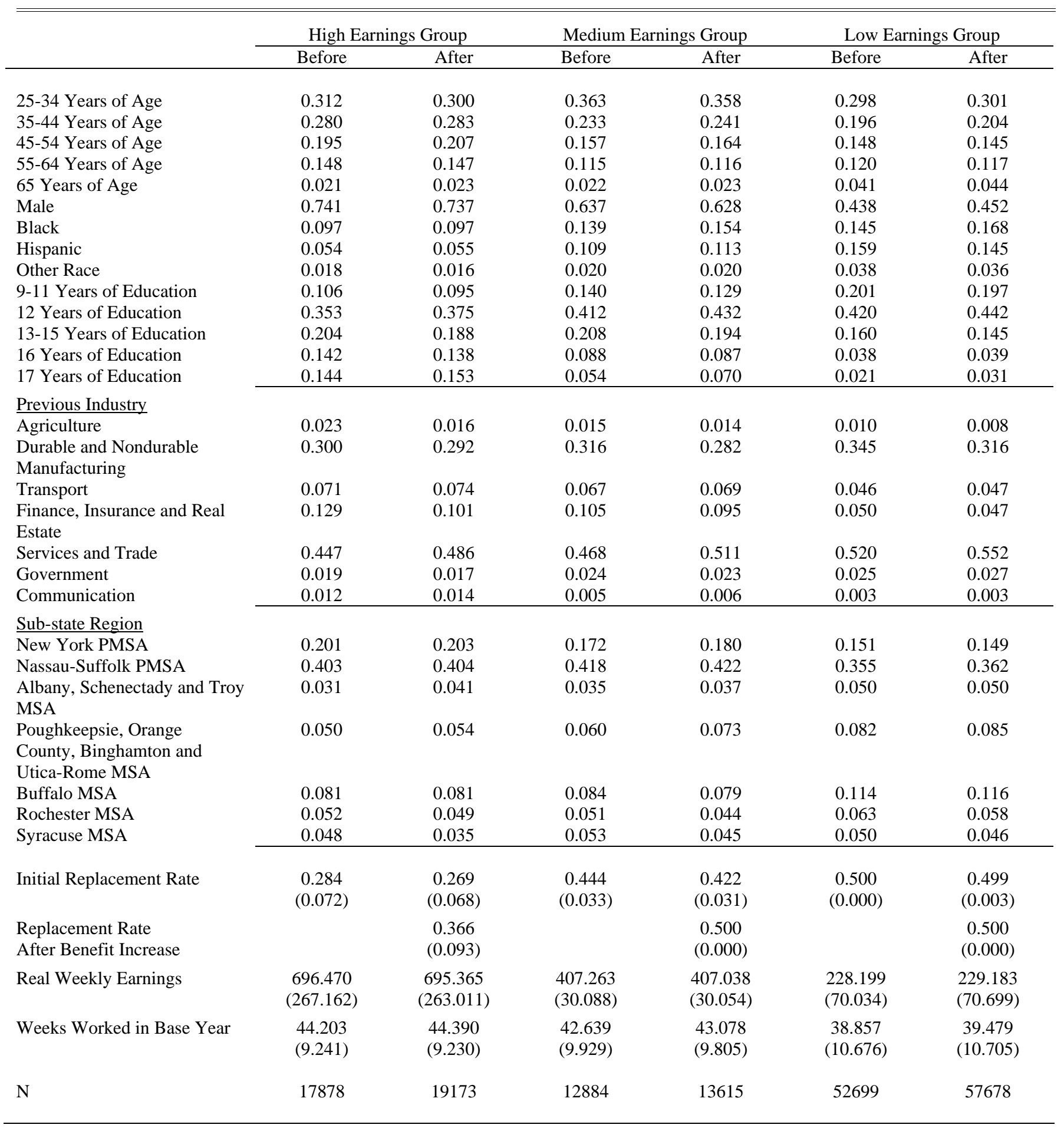

Notes: (1) Standard deviations are in parentheses. (2) Only Q1 observations are included, those with missing demographics, no previous earnings, with weeks worked less than 20, real weekly earnings less than $\$ 80$ (\$84.24 in 1989 ), out of state observations and those in construction, with pension reductions are deleted. (3) Initial Replacement Rate is defined as the ratio of the benefit amount in the first week of claim to the person's average weekly earnings. 
Previous Weeks Worked: Number of weeks worked in the base year.

Average Weekly Earnings: Base year earnings divided by weeks worked in the base year. Base year earnings are the earnings in the last 52 weeks prior to the week of filing.

Week Spell Began: 13 indicator variables for the first 13 calendar weeks. Equals one if the individual's claim began in the particular week.

Age: Indicator variables for age 25-34, 35-44, 45-54, 55-64, and 65+.

Race: Indicator variables for black, Hispanic, and other non-white groups.

Education: Indicator variables for years of education 9-11, 12, 13-15, 16, and 17 or more.

Gender: Indicator variable for male.

Industry: Indicator variables for agriculture, durable manufacturing, nondurable manufacturing, transport, FIRE (finance, insurance and real estate), services, government, trade and communication. The reference industry is trade.

Sub-state Region: Indicator variables for New York City, Bronx, Suffern, Westchester, Long Island, Riverhead, AST (Albany, Schenectady and Troy), Kingston, Poughkeepsie, Monticel, Glenfall, Platts, Syracuse, Utica, Water, Binghamton, Buffalo, Rochester, James and Elmira. The reference region is James.

High Earnings Group: Indicator variable for those whose real average weekly earnings (in 1988 dollars) are above $\$ 465.34$.

Medium Earnings Group: Indicator variable for those whose real average weekly earnings (in 1988 dollars) are between $\$ 360$ and $\$ 465.34$.

Low Earnings Group: Indicator variable for those whose real average weekly earnings (in 1988 dollars) were between $\$ 80$ and $\$ 360$.

After Increase: Indicator variable for those who filed a claim in 1989.

WBA under Old Law: Amount of weekly benefits under the law prior to the increase. It is $50 \%$ of nominal average weekly earnings for those with nominal average weekly earnings between $\$ 80$ and $\$ 360$. For those with average weekly earnings over $\$ 360$, it is $\$ 180$.

WBA under New Law: Average amount of weekly benefits under the law after the increase assuming a 20 week spell beginning with the file date. Weekly benefit amount from the date of increase is $50 \%$ of nominal average weekly earnings for those with nominal average weekly earnings between $\$ 80$ and $\$ 490$. For those with average weekly earnings over $\$ 490$, it is $\$ 245$. 
$\underline{\text { Additional variables in duration models }}$

Calendar Week: Indicator variables for each calendar week the person is at risk in the person-week format of the data (38 $\times 2$ variables).

Ln(Earnings) Spline: The positive part of the difference between Ln(Real Average Weekly Earnings) and the logarithm of each decile of real average weekly earnings in the sample ( 9 variables in addition to Ln(Earnings)). 